THE BENEFITS OF PRIVATIZATION:

EVIDENCE FROM MEXICO

Rafael La Porta

Florencio Lopez-de-Silanes

Working Paper 6215 
NBER WORKING PAPER SERIES

\title{
THE BENEFITS OF PRIVATIZATION: EVIDENCE FROM MEXICO
}

\author{
Rafael La Porta \\ Florencio Lopez-de-Silanes
}

Working Paper 6215

http://www.nber.org/papers/w6215

\author{
NATIONAL BUREAU OF ECONOMIC RESEARCH \\ 1050 Massachusetts Avenue \\ Cambridge, MA 02138 \\ October 1997
}

We are grateful to Karine Del Paso, Magdalena Lopez-Morton and Priscilla Muñoz for excellent research assistance, to Andrei Shleifer, Roberto Villarreal, Luigi Zingales and seminar participants at MIT and NBER for useful comments and suggestions. We would also like to thank Miguel Cervera Flores and Francisco Piñeda of INEGI for assisting us with data, and Santiago Levy, Jorge Silberstein, and Roberto Villarreal of the Ministry of Finance for allowing us access to the privatization files. The second author acknowledges research support from the Dean's Research Fund of the Kennedy School of Government and from the David Rockefeller Center for Latin American Studies at Harvard University. This paper is part of NBER's research programs in Corporate Finance and Public Economics. Any opinions expressed are those of the authors and not those of the National Bureau of Economic Research.

(C) 1997 by Rafael La Porta and Florencio Lopez-de-Silanes. All rights reserved. Short sections of text, not to exceed two paragraphs, may be quoted without explicit permission provided that full credit, including $\mathbb{C}$ notice, is given to the source. 
The Benefits of Privatization: Evidence

from Mexico

Rafael La Porta and Florencio Lopez-de-Silanes

NBER Working Paper No. 6215

October 1997

Corporate Finance and Public Economics

\section{ABSTRACT}

Criticisms of privatization have centered around the possibility that the observed higher profitability of privatized companies comes at the expense of the rest of society. In this paper we focus on two of the most likely channels for social losses: (1) increased prices as firms capitalize on their market power; and (2) layoffs and lower wages as firms seek to roll back generous labor contracts. Using data for all 218 non-financial privatizations that took place in Mexico between 1983 and 1991 we find that privatized firms quickly bridge the pre-privatization performance gap with industry-matched control groups. For example, privatization is followed by a 24 percentage point increase in the ratio of operating income to sales. We roughly decompose those gains in profitability as follows: 10 percent of the increase is due to higher product prices; 33 percent of the increase represents a transfer from laid-off workers; and productivity gains account for the residual 57 percent. Transfers from society to the firm are partially offset by taxes which absorb slightly over half the gains in operating income. Finally, we also find evidence indicating that deregulation is associated with faster convergence to industry benchmarks.

Rafael La Porta

Department of Economics

Harvard University

Cambridge, MA 02138
Florencio Lopez-de-Silanes

Harvard University

Littauer Center, Room 110

79 John F. Kennedy Street

Cambridge, MA 02138

and NBER

f_lopezdesilanes@harvard.edu 


\title{
The Benefits of Privatization: Evidence from Mexico
}

\author{
Rafael La Porta and Florencio Lopez-de-Silanes ${ }^{1}$
}

Harvard University

August 21, 1997

\begin{abstract}
Criticisms of privatization have centered around the possibility that the observed higher profitability of privatized companies comes at the expense of the rest of society. In this paper we focus on two of the most likely channels for social losses: (1) increased prices as firms capitalize on their market power; and (2) layoffs and lower wages as firms seek to roll back generous labor contracts. Using data for all 218 non-financial privatizations that took place in Mexico between 1983 and 1991 we find that privatized firms quickly bridge the pre-privatization performance gap with industry-matched control groups. For example, privatization is followed by a 24 percentage point increase in the ratio of operating income to sales. We roughly decompose those gains in profitability as follows: 10 percent of the increase is due to higher product prices; 33 percent of the increase represents a transfer from laid-off workers; and productivity gains account for the residual 57 percent. Transfers from society to the firm are partially offset by taxes which absorb slightly over half the gains in operating income. Finally, we also find evidence indicating that deregulation is associated with faster convergence to industry benchmarks.
\end{abstract}

\section{Introduction}

In the last decade, a number of countries have launched ambitious privatization programs. Despite this growing experience, our empirical knowledge of some critical issues is still fairly limited: Aside from theoretical predictions, how well does privatization work in practice? Do firms become more profitable? If so, what roles do market power and increases in output prices play in explaining improvements in the performance of privatized firms? Does the increased profitability of privatized firms result from the expropriation of workers? How important is deregulation for the success of privatization? In this paper we seek to provide some empirical answers to these questions based on the privatization that has taken place

\footnotetext{
${ }^{1}$ We are grateful to Karine Del Paso, Magdalena Lopez-Morton and Priscilla Muñoz for excellent research assistance, to Andrei Shleifer, Roberto Villarreal, Luigi Zingales and seminar participants at MIT and NBER for useful comments and suggestions. We would also like to thank Miguel Cervera Flores and Francisco Piñeda of INEGI for assisting us with data, and Santiago Levy, Jorge Silberstein, and Roberto Villarreal of the Ministry of Finance for allowing us access to the privatization files. The second author acknowledges research support from the Dean's Research Fund of the Kennedy School of Government and from the David Rockefeller Center for Latin American Studies at Harvard University.
} 
in Mexico.

Criticisms of privatization have centered on the possibility that the observed higher profitability of privatized companies has come at the expense of the rest of society through the exploitation of market power. Critics often appeal to a tradition in economics that regards state-owned enterprises (SOEs) as instruments capable of curing market failures by implementing pricing policies that take account of social marginal costs (social view, Shapiro and Stiglitz, 1990). An equally prominent argument against privatization is that the burden of the restructuring cost has fallen upon the workers through layoffs and wage cuts. In contrast, the more recent economic literature has taken a much less flattering view of SOEs and a more favorable view of privatization. This literature emphasizes agency conflicts as the source of the inefficiency of SOEs (agency view). There are two complementary strands of the literature according to whether the critical agency conflict is with the manager or with the politician. Vickers and Yarrow (1988) argue that managers of SOEs may lack high-powered incentives or may not be properly monitored (managerial view). In turn, Shleifer and Vishny (1994) stress that political interference in the firm results in excessive employment, poor choices of product and location, lack of investment, and ill-defined incentives for managers (political view) ${ }^{2}$ In sum, the theoretical literature points to some benefits of privatization --especially higher profitability-but also recognizes its potential costs.

The existing empirical literature has not yet effectively compared the costs and benefits of privatization. Early empirical research compares SOEs and private firms in the same line of business, such as railroads and air transportation, finding mixed evidence that the latter are more efficient (Caves, 1990, and Boardman and Vining, 1992). More recent research finds private ownership to be more efficient, in general, than public ownership. For example, Megginson et al. (1994) find that the performance of SOEs improves moderately following privatization for a sample 61 international initial public offerings (IPOs). ${ }^{3}$ Similarly, Donahue (1989) summarizes evidence of the lower cost involved in contracting public services to private suppliers rather than providing them in-house. Although recent work has started to provide some evidence on the transformation of privatized firms, it is difficult to distinguish between the social view and the agency view just by looking at privatization outcomes. For example, while the agency view predicts that privatization will result in higher profits, the social view makes the same prediction if, for example, market power is prevalent. Empirical evidence on the channels through which privatization raises profits is essential in order to distinguish between these competing views of state ownership.

\footnotetext{
${ }^{2}$ See also, Shapiro and Willig (1990) on the political view.

${ }^{3}$ See also Galal et al. (1992) and World Bank (1995).
} 
Our paper makes three contributions to the literature. First, we document the effects of privatization on seven general areas: (1) profitability; (2) operating efficiency; (3) employment and wages; (4) capital investment; (5) taxes; (6) output; and (7) prices. Second, we provide empirical evidence for two possible ways in which gains by privatized firms may come at the expense of the rest of the society: monopoly power and transfers from workers. Third, we focus on the role of deregulation. Privatization is often accompanied by changes in regulation. Deregulation is interesting as a control since it may have a large impact on outcomes and add a confounding effect when it accompanies privatization. Deregulation is also of independent interest to the extent that it complements privatization by, for example, fostering product market competition. Vigorous product market competition may play a role in accelerating the restructuring process by facilitating the elimination of poorly managed firms (Armstrong et al., 1994). Product market competition may also speed up the depoliticization of privatized firms by increasing the costs of political intervention (Shleifer and Vishny, 1994).

To evaluate the benefits of privatization, we have collected data on all 218 non-financial firms privatized in Mexico in the period 1983-1991. ${ }^{4}$ In the period before privatization, the Mexican State was involved in nearly every sector of economic activity. In 1983, the government launched a privatization program which dismantled government operations in 49 different industries, as defined by four-digit SIC codes. The conclusions drawn from previous research on privatization maybe misleading given that the unavailability of data has, so far, confined research to the analysis of public utilities and large firms in oligopolistic markets. We believe that the database that we have assembled is free from the biases that may be present in incomplete samples because it includes both privately owned and publicly traded firms, spanning a wide variety of sectors. Our database is also unique in that it contains detailed wage data as well as product-level quantities and prices which allows us to provide more direct evidence on the validity of the competing hypotheses on privatization.

Section II describes the Mexican privatization program and the data. Section III presents the basic empirical results on the effects of privatization. Section IV looks at the role of market power in explaining the obseryed changes in performance. Section $V$ examines the role of transfers from workers to shareholders. Regression results are presented in Section VI. Section VII concludes.

\footnotetext{
${ }^{4}$ We exclude financial institutions for two reasons. First, the accounting ratios of financial institutions and those of manufacturing and service firms are not easily comparable. Second, half of the financial institutions, ie. 11, were privatized during 1992. Since 1993 is the only year for which we have post-privatization data, we decided to exclude all privatizations that took place on 1992 on the grounds that we wanted to allow at least two years for the impact of privatization to show up. Thus, at most we could include only half the privatized financial institutions. Lopez-de-Silanes and Zamarripa (1996) focus exclusively on the privatization of banks in México.
} 


\section{The Sample}

\section{A. The Mexican Privatization Program}

The Mexican privatization program is one of the most extensive in the world in terms of both size and number of companies privatized. ${ }^{5}$ Before the debt crisis in 1982, the Mexican state had been actively involved in the economy through SOEs which had been created with the intention of attending a multiplicity of goals: the improvement of infrastructure, import substitution, regional development, and the creation of jobs. In 1982, there were 1,155 SOEs in Mexico and they participated in nearly every sector of the economy. In that year, subsidies and transfers to SOEs equaled 12.7 percent of GDP. SOEs' output accounted for 14 percent of GDP, they employed 4.4 percent of the country's labor force, and they accounted for 38 percent of fixed capital investment.

The unraveling of the state sector began in 1983. Over the next two years, the number of SOEs was greatly reduced through mainly liquidations and mergers. Privatization did not truly take off until 1985. But by June of 1992, 361 SOEs had been privatized and the number of firms remaining under state ownership had been reduced to 225 . Overall, 96 percent of all assets privatized were sold during the period 1989-1992 under the administration of President Salinas. By 1992, the government had withdrawn from most sectors of the economy with the exception of oil, petrochemicals, and the provision of major infrastructure services (such as gas, water, electricity, highways, railways and ports).

The method of privatization employed in Mexico involved first price sealed-bid auctions. ${ }^{6}$ Companies were divested under different auction requirements. For example, in sixty-four cases of our sample, bidders were required to submit a fairly detailed investment plan. In another six cases, the government required the winner to meet all the previous contracts of the SOE. Nevertheless, the value of the bid was the determining factor in the selection of the winner in over 98 percent of all privatized SOEs. Sales of control or majority holdings represented 90 percent of the total number of privatization contracts, while the remaining 10 percent involved sales of government minority ownership. Except for eight cases, the government sold 100 percent of its ownership in each transaction. In the remaining eight cases, the government retained a minority stake which was sold at a later date. Compared with similar programs in Eastern and Western Europe, Mexican privatization was almost always accompanied by changes in senior management. In fact, the government-

\footnotetext{
${ }^{5}$ See Kikeri et al. (1994) for a survey of privatization programs around the world.

${ }^{6}$ Mexico, unlike other nations, never resorted to public subscriptions through the stock market as a privatization mechanism. This does not mean that there are no publicly traded firms in our sample. In fact, eleven firms in our sample were already publicly traded at the time of their privatization and remained so after privatization. However, even in these eleven cases, the government chose to privatize through first-price sealed-bid auctions rather than offer new shares in the stock market.
} 
appointed management team retained power only in the six firms that were sold to the SOE's management. ${ }^{7}$

\section{B. Data}

Our sample is drawn from the population of 233 non-financial privatization contracts signed over the period 1983-91. ${ }^{8}$ The number of privatization contracts is much smaller than the number of privatized firms because many companies were sold as members of multi-firm conglomerates. We were able to collect preprivatization firm-level data on 218 of those contracts from audited financial statements using the privatization prospectuses and other primary documents kept in the archives of the Mexican Ministry of Finance and Public Credit as our sources. ${ }^{9}$ Fifteen transactions, accounting for less than 1 percent of all the privatized assets, could not be included since they lacked complete financial information for the preprivatization period. Table I groups the privatization contracts in our sample according to four-digit industry codes. Privatization spans across multiple industries, ranging from steel conglomerates and airlines to a popular soccer team.

To collect post-privatization data, we requested the information of the privatized firms contained in the 1994 Economic Census from the Mexican National Statistics Institute (INEGI). We complemented INEGI's data with additional information collected from nine written questionnaires sent in June of 1996 and from the financial reports of all publicly traded companies. Table II shows the results of our efforts to gather postprivatization data. As the table indicates, we have complete post-privatization data for 170 firms which account for 97.31 percent of the total sales, 97.17 percent of the total assets and 92.10 percent of the total employment of the sample at the time of privatization. Nine companies could not be included since they merged and no longer kept separate financial statements. INEGI could not find records for an additional twenty-six firms probably due to either clerical errors or incomplete census records. These unaccounted firms tend to be small. For example, unaccounted firms represent only 1.69 percent of the sales of the sample at the time of privatization. We know that none of these twenty-six firms went bankrupt since their names are not listed in Diario de la Federación, the official publication of the Mexican government that

\footnotetext{
${ }^{7}$ Not included in those six cases are twenty-nine joint-ventures between the state and private firms in which the government's stake was acquired by the private partner in the joint-venture.

${ }^{8}$ Eleven financial firms were sold over the period 1983-91.

${ }^{9}$ The accounting procedures followed in the preparation of privatization prospectuses are virtually identical to those followed by the private sector which ensures the comparability of the pre- and post-privatization samples.
} 
(among other things) announces the initiation of bankruptcy proceedings..$^{10}$ Liquidations are a relatively rare occurrence in our sample. In fact, only thirteen firms representing 0.83 percent of the total sales of the sample at the time of privatization were liquidated.

In principle, the figures in the pre- and post-privatization samples are comparable because the audited financial statements included in the privatization prospectuses are prepared under the same accounting procedures followed by the private sector. Testing whether the data is compatible is difficult because SOEs typically do not publish annual reports. Nevertheless, we performed two checks of the quality of our data. First, we compared the post-privatization data reported to INEGI with the annual reports of all publicly traded firms in the sample. Second, we compared the pre-privatization data in the privatization prospectus with the annual report of all publicly-traded SOEs in the sample. In both cases we discovered only minor discrepancies between INEGr's data and published annual reports. Asset sales are another possible source of measurement error when comparing pre- and post-privatization data as divestitures are frequent in the post-privatization period. Since we have establishment-level data, we avoided the difficulties created by asset sales by treating all establishments sold in the post-privatization period as if they were still owned by the old SOE. ${ }^{11}$

Ultimately we are interested in analyzing the change in performance of our sample of firms following privatization. We rely on seven broad indicators of performance: (1) profitability; (2) operating efficiency; (3) employment and wages; (4) capital investment; (5) taxes; (6) total output; and (7) prices. Table III summarizes our data and sources. For each firm, we measure the change in any given indicator of performance by comparing its value in 1993 to its average value of the four years preceding privatization (i.e., year $\mathrm{t}-4$ to $\mathrm{t}-1)^{12,13}$. Since our post-privatization data is limited to 1993 , simple comparisons of pre- and

\footnotetext{
${ }^{10}$ We were able to contact most of these twenty six firms by telephone. Nevertheless, INEGI could not locate their census records.

${ }^{11}$ Specifically, obtaining data for privatized firms involved a two step procedure. First, INEGI matched the census data with the name, address, and industrial code of all the establishments owned by the SOE when it was privatized. Second, INEGI searched for new establishments owned by the privatized SOE using unique identifying numbers assigned to each firm at the time of the census.
}

${ }_{12}$ All the data is expressed in thousands of new pesos of 1993 using the consumer price index as deflator. In December of 1993, US \$1 was equivalent to 3.1 new pesos.

${ }^{13}$ We used the average value of the four years preceding privatization as the benchmark to reduce measurement error. Since measurement error could result from a variety of sources, it is unclear how it would bias the results. On one hand, relying on the last-available pre-privatization data may understate the gains from privatization since the Mexican government often tried to restructure firms before their privatization to increase their attractiveness. On the other hand, relying on the last-available pre-privatization data may overstate the gains from privatization if, for example, government officials tampered with financial records to benefit friendly parties in the auction. In this case, using four-year averages would mitigate the bias since any tampering with financial records is likely to have 
post-privatization performance involve averaging over firms that differ in the number of years that have been operating as private entities. ${ }^{14}$ In practice, we believe that this problem is not a very serious one given that it takes firms in our sample approximately two years to complete the restructuring process that follows privatization. Also, regressions in Section VI address the problems created by differing privatization cohorts.

We employ local currency data in all our analysis, and, whenever possible, we compute ratios using nominal data in both the numerator and denominator. We express all nominal figures in thousands of new pesos (N\$) of 1993. The choice of deflator is not irrelevant since the CPI series shows higher inflation than the PPI series over the sample period. We use the PPI index to adjust all product prices and the CPI index to adjust the values of all the remaining nominal quantities. The only choice that is questionable is that of CPI since it imparts a conservative bias against finding significant increases in sales, earnings, fixed assets, wages and taxes.

We calculate four profitability ratios: operating income to sales, net income to sales, operating income to fixed assets, and net income to fixed assets. The net income measure that we use does not include any direct subsidies received by the firm. In other words, suppose that an SOE receives $\$ 1$ from the Treasury and that its losses from the sale of goods and services is $\$ 1$. In such case, we report a loss of $\$ 1$ as our net income number. We ignore all indirect subsidies since sufficient data to quantify them is not available. Net income --but not operating income-- is affected by the changes in leverage that often accompany privatization. Evaluating changes in operating-income offers a superior measure of efficiency gains whereas evaluating changes in net-income provides a useful summary statistic of the full impact of privatization on the performance of SOEs. The two profitability ratios that are scaled by fixed assets (PPE) may be somewhat less reliable than those that are scaled by sales because the rules on how to adjust the value of PPE for past inflation were changed in 1991.

We also look at four indicators of operating efficiency to capture changes in the ability of firms to extract output from any given level of inputs. We compute the ratio of cost-per-unit --defined as the cost of labor and intermediate inputs--to sales, log of sales per unit of PPE, and the log of sales per employee. Finally, we look at the ratio of operating income to employment.

The next set of indicators deals with labor. Some of the recent public controversy about privatization

\footnotetext{
been confined to the period that follows the announcement of the SOE's privatization, which is roughly two years. In practice, measurement error is probably not large for financial data since our reported results are robust to the use of different pre-privatization benchmarks (see, for example, Figures II through IV). In contrast, employment changes are sensitive to the choice of pre-privatization benchmark (see Figure I and the discussion in Section III).

${ }^{14}$ The mean (median) firm in our sample had been privatized 4.25 (4) years earlier.
} 
(e.g., in England) has focused on the rapid rise of executive compensation relative to non-executive pay. The most effective way to address these distribution issues with our data is by comparing outcomes for blue and white collar workers. Overall, we have good employment data but, unfortunately, only 60 percent of the firms report detailed pre-privatization wage data. We analyze three indicators of employment: the $\log$ of total employment, the log of blue collar employment and the log of white collar employment. Similarly, we compute three wage indicators paralleling our employment measures: the average wage per worker, the average wage of a blue-collar worker and the average wage of a white-collar worker.

To assess the impact of privatization on capital formation we look at both the stock of fixed assets and at the level of investment. Specifically, we examine the log of fixed assets and the log of fixed assets per employee. We also look at the ratio of investment to fixed assets. Finally, we compute the ratios of investment over sales and investment per employee.

Taxes are another worthwhile variable to consider since privatization is often motivated by the need to reduce the burden imposed by SOEs on public finances. We define net taxes as taxes paid net of direct subsidies and consider their absolute value, as well as the ratio of net taxes to sales.

Finally, we examine the behavior of output and prices. Our measure of output is simply the log of (real) sales. To analyze the behavior of prices, we compute a Paasche price index for each firm which measures the change in prices in the post-privatization period. The firm-level price index is based on annual data on both the prices and the physical quantities sold for each of the main products/services of the firm. ${ }^{\text {is }}$ In order to isolate the firm's changes in relative prices, we report the firm-level price index net of the growth in the producer price index during the post-privatization period.

Whenever possible we control for macroeconomic and industry factors. This is achieved by computing the same indicators used to describe the performance of privatized firms for a control-sample of private firms with the same three-digit SIC code. We use economy-wide aggregates, if available, for those firms for which we cannot find a matched industry sample. As a rule, we form control groups based on data gathered from the financial reports of all non-SOEs that trade on the Mexican stock market. Whenever stock market data is available, the procedure used to compute industry-adjusted statistics is straightforward: for each year, we use firm-level data for all non-SOEs that trade on the Mexican stock market in order to compute analogs to the performance indicators that we use to describe the behavior of privatized firms. Then we compute industry-adjusted indicators for each year by taking the difference between the value of the indicator for each

\footnotetext{
${ }^{15} \mathrm{~A}$ Paasche index of prices is computed by taking the ratio of the total value of post-privatization sales to the weighted sum of the pre-privatization physical quantities sold, were the weights are the post-privatization quantities.
} 
SOE and the average of its industry analog across all firms in the SOE's control group. The only cases in which our control groups are not based on publicly traded firms is when performance indicators require data on wages and employment since labor data is not available for firms in the stock market. In the case of salesper-employee we compute our industry benchmark using three-digit level SIC data on sales and employment data for the sample of manufacturing firms as reported in the Monthly Survey of Manufacturing Firms. ${ }^{16}$ We are unable to form industry-control groups for wages and rely instead on an economy-wide wage index as the benchmark. Finally, operating-income-per-employee and investment-per-employee analogs are unavailable on even an economy-wide level.

\section{Basic Results}

\section{A. Raw Data}

Our basic results are presented in Table IV. Several interesting results are immediately noticeable. Profitability increases significantly after privatization according to all four indicators. The SOEs in our sample are highly unprofitable in the pre-privatization period: the median net-income-to-sales ratio is -12.97 percent. The mean (median) change in profitability from the pre-privatization average to 1993 ranges from a low of 24.1 percentage points (12.8) for operating-income-to-sales to a high of 39.9 percentage points (20.5) for net-income-to-sales. All t-statistics and Z-statistics are significant at 1 percent. These sharp increases in profitability are greater than previous findings of the literature. For example, Megginson et al. (1994) report that, in the three years following privatization, the cumulative mean (median) change in the net-income-to-sales ratio in their sample of international IPOs is 7.5 percentage points (4.2).

Large increases in operating efficiency underpin these gains in profitability. The average (median) costper-unit plummets 21.49 percent (16.76 percent). At the same time, average (median) sales-to-PPE rises 64.64 percent ( 23.85 percent) and both average and median sales-per-employee nearly doubles. The impact on the bottom line of the higher level of sales-per-employee is dramatic: average (median) operating-incomeper-employee raises from $\mathrm{N} \$ 1.67(-\mathrm{N} \$ 0.68)$ to $\mathrm{N} \$ 54.17$ (N\$14.41). Once again, all changes are significant at the 1 percent level.

Employment cuts are a big part of the story. The numbers of both white and blue collar workers employed are nearly halved. The mean (median) number of white collar workers falls by 53.5 percent ( 46.3 percent) while the mean (median) number of blue collar workers falls by 53.4 percent ( 60.9 percent). As dramatic as these figures are, they still underestimate the layoffs experienced by privatized firms. Recall

${ }^{16}$ We use the sample wide ratio of sales per employee as control for all non-manufacturing firms. 
that the pre-privatization figures that we report are based on the average number of employees over the four years that precede actual privatization. However, as Figure 1 shows, the level of employment was steadily falling throughout the pre-privatization period. Most likely, the pre-privatization fall in employment is the result of the government's efforts to revamp the firms before divesting them. In fact, using only those observations for which we have complete employment data for all four pre-privatization years (117), we find that the mean (median) number of workers falls 16.53 percent ( 4.19 percent) between $t-4$ and $t-1$ and a further 62.36 percent ( 64.74 percent) between $t-1$ and 1993, where $t$ is the year of privatization. ${ }^{17}$ These findings on labor cuts suggest that transfers from workers to shareholders play a role in the success of privatization. However, we will postpone the analysis of these issues until Section 5.

Ex-ante we did not expect to see large changes in investment given that, on average, half of the installed capacity was idle in the year before privatization. ${ }^{18}$ However, privatized firms may still have reasons to undertake investments if the SOEs capital equipment is obsolete or geared to produce goods that do not have a market. Nonetheless, the data confirms the initial presumption that investment by privatized firms is low. The stock of fixed assets is mostly unchanged (its mean and median move in opposite directions). However, our investment indicators--which may be less susceptible to measurement error--point towards a moderate increase in the rate of capital accumulation. The mean (median) investment-to-sales rises from 2.99 percent ( 0.22 percent) to 4.49 percent ( 1.25 percent). The investment-to-PPE ratio exhibits comparable increases: its mean (median) rises from 2.44 percent ( 0.40 percent) to 7.18 percent ( 2.56 percent). Fixed-assets-peremployee increase as a result of the large cuts in employment: the average (median) fixed-assets-peremployee rise 20.21 percent (50.36 percent). However, note that only the change in median $\log \left(\mathrm{PPE} /\right.$ Employee) is statistically significant (at 10 percent) ${ }^{19}$

Perhaps the most surprising finding of this section is that privatized firms are able to increase their sales despite more than halving their workforce and increasing their stock of capital modestly at best. In fact, the growth in (real) sales is nothing short of spectacular as the mean (median) sales rise 54.28 percent (68.16

\footnotetext{
${ }^{17}$ In contrast with our finding of sharp cuts in employment, Megginson et al. find employment roughly 5 percent larger three years after privatization than at the time of divestiture. Megginson's finding stands at odds with labor's reluctance to embrace privatization. We do not know what explains the discrepancy between our result and theirs. It is possible that Megginson's sample of international IPOs represent a self-selected sample of those SOEs with the highest growth opportunities.

${ }^{18}$ We do not report capacity utilization in Table IV since it is not available in 1993.

${ }^{19}$ A branch of the literature (see, for example, Laffont and Tirole, 1993) emphasizes that the fear that the state may expropriate assets of the firm that have alternative social uses is the main source of inefficiencies in SOEs as it results in under-investment. We find no evidence that under-investment by SOEs was an important factor of inefficiency in Mexico.
} 
percent).

The behavior of prices is also of considerable interest. The mean (median) increase in the firm's prices relative to the PPI index is only 2.87 percent ( 1.27 percent). ${ }^{20}$ Product-level information on prices is available for approximately one-half of the sample ( 83 observations). The most frequent reason why we are unable to compute the price index are inconsistencies in the reporting units between the pre- and post-privatization periods. In six cases, changes in product lines prevent us from calculating the price index. It is not obvious which types of biases may be present in the sub-sample of firms with usable product-level information on prices. The sub-sample seems to be biased towards larger, more visible, firms since the percentage of oligopolistic and monopolistic firms --as defined in Section 4-- in the subsample with product-level data is greater than in the original sample.

One way to gauge the contribution of price hikes to the observed change in profitability is to compare the observed percentage points increase in operating-income-to-sales to that which would take place if privatized firms had increased output but left prices unchanged (in real terms) at pre-privatization levels. Specifically, we define Sales $_{1993}$ and Cost $_{1993}$, respectively, as net sales and opcrating costs in the postprivatization period and $\pi$ as the increase in real prices, and compute the following measure for the contribution of price increases to higher profitability:

$$
\text { Price Contribution }=\frac{\text { Sales }_{1993}-\text { Cost }_{1993}}{\text { Sales }_{1993}}-\frac{\frac{\text { Sales }_{1993}}{1+\pi}-\text { Cost }_{1993}}{\frac{\text { Sales }_{1993}}{1+\pi}}
$$

Performing the above described calculation using sample-wide mean (median) figures for sales, costs and inflation suggests that price increases account for a gain of $2.62(1.15)$ percentage points in the ratio of operating income to sales. Accordingly, price increases explain 10.88 percent $(=2.62 / 24.11)$ of the observed change in mean operating-income-to-sales and 9.52 percent $(=1.15 / 12.08)$ of the change in the observed median operating-income-to-sales.

Finally, responding to politicians' prayers, privatized firms become significant tax contributors. The average firm moves from receiving a small subsidy to paying $\mathrm{N} \$ 25,675$ (approximately, US\$8.3 million).

${ }^{20}$ As a robustness check, we also computed a Laspayres index of prices which shows a mean (median) increase of 3.29 (1.72) percent relative to the PPI index. 
The tax-to-sales ratio tells a similar story: the mean (median) tax rises from -4.62 percent $(0.00$ percent) of pre-privatization sales to 8.39 percent ( 7.63 percent) of post-privatization sales.

\section{B. Industry-Adjusted Data}

During the early 1990s, the Mexican economy expanded rapidly and experienced great sectoral transformations (see, for example, Lustig, 1992). Therefore, one may wonder whether the rapid sales' growth and large increases in profits witnessed in privatized firms are manifestations of these macroeconomic and industry factors. To isolate the role of privatization, we present industry-adjusted ratios in Table V.

Table $\mathrm{V}$ allows us to rule out macroeconomic and industry factors as the driving forces behind the large increases in post-privatization sales. The table shows that growth in sales remains very strong even relative to industry: the mean (median) industry-adjusted growth in sales is 42.39 percent (48.91 percent). Improvements in overall industry conditions can account for only about one-fifth of the average growth in sales (i.e., 11.9 percentage points out of a total of 54.3).

The key finding that emerges from the industry-adjusted ratios is that in 1993 the profitability of an average SOE is very similar (and in fact, statistically indistinguishable) from that of its private sector peers despite having previously underperformed this control group by as much as 26 to 40 percentage points (depending upon the benchmark ratio chosen). Figures II and III illustrate this point by showing the behavior of the median operating-income-to-sales ratio and the median net-income-to-sales ratio, respectively, through time for both the sample of SOEs and the control group of publicly traded firms. For example, Figure 2 shows a fairly consistent gap between the private and public sector median operating-income-tosales ratio during the pre-privatization period. By 1993, privatized firms had completely closed the gap and, indeed, surpassed the control group by 1.77 percentage points. Operating efficiency is the mirror image of the gain in profitability (see Figure 4). In 1993, unit costs of privatized firms are identical to those of the control group although they were, on average, 18.25 percentage points higher in the pre-privatization period.

The other finding of Table $\mathrm{V}$ is that privatization is not followed by the burst of investment for which government officials frequently hope. In 1993, the mean (median) ratio of investment-to-sales of privatized firms is 3.61 (5.8) percentage points lower than that of the control group. In contrast, SOEs' investment behavior matched that of the control group during the pre-privatization period. Lastly, after controlling for industry factors, the average (median) annual growth in employment in the post-privatization period is $\mathbf{- 8 . 1 5}$ percent $(-6.47$ percent). 
The findings in this section are easily summarized: sales increase quickly in the post-privatization period although the stock of fixed assets remains basically unchanged and the number of workers falls sharply. This increased efficiency coupled with higher level of sales for privatized firms translates into large gains in profitability. The key question is whether the higher profit level is the result of enhanced productivity or of higher markups. The industry-adjusted ratios suggest that privatized firms are "catching up" to the profitability and operating efficiency of their peers in the private sector. We turn to the role of market power in the next section for further analysis.

\section{The Role of Market Power}

In this section we try to assess the role of market power in explaining the success of privatized firms. First, we analyze changes in profitability for firms grouped on the basis of various proxies for market power. Second, we analyze the behavior of product-level prices for a subsample of firms for which we have such data.

Market power is an elusive concept. To ensure the robustness of our findings, Table VI breaks down our performance results into competitive and non-competitive sectors using three alternative definitions of market power.

The first breakdown classifies firms as competitive and non-competitive according to the description of the industry provided in the privatization prospectus. According to this criterion, a firm is classified as noncompetitive if it operates in a sector deemed as either monopolistic or oligopolistic by the financial consultants who produced the privatization prospectus. The results in Panel A show that profitability is higher in non-competitive than in competitive sectors both before and after privatization. Surprisingly the median changes in both operating income ratios (i.e., operating-income-to-sales and operating income-toPPE) are higher in competitive industries than in non-competitive ones. Focusing on operating-income-tosales yields the most favorable comparison for the competitive sector: the median operating-income-to-sales ratio increases by 14.57 percentage points compared with 8.45 in the non-competitive sector (note that the difference is not statistically significant). This data does not support the view that market power is the driving force behind the results of our previous two tables.

In contrast, both net-income-to-sales and net-income-to-PPE rise more in the non-competitive sector than in the competitive one. For example, the median net-income-to-sales rises by 20.78 percentage points in the competitive sector versus 35.40 percentage points in the non-competitive sector. The margin by which the non-competitive sector outpaces the competitive one drops to 3.27 percentage points if we look at net- 
income-to-PPE. Neither of the difference in median changes in our net-income ratios are statistically significant.

By construction, three factors can account for the opposing behavior of operating-income and netincome: taxes, extraordinary items, and interest expense. We can rule out taxes as the explanation since all three criteria of market power show that the increase in paid taxes is larger for non-competitive firms than competitive firms. Changes in leverage is a more promising explanation. Megginson et al. (1994) show that newly privatized firms cut their debt levels, perhaps because their debt is no longer backed by the implicit guarantee of the state. For this reason, operating-income is a better gauge of the impact of market power on profits than net-income since the former is not affected by changes in leverage while the latter is. We conjecture--but do not have the data to test--that firms in oligopolistic and monopolistic sectors exhibit greater reductions in leverage in the post-privatization period than firms in competitive ones, perhaps because of the greater access to government-backed capital they enjoyed during the pre-privatization period.

The number of firms in non-competitive sectors with product-level information on prices (16) is insufficient to draw statistically significant comparisons with the competitive sector. The median cumulative increase in the prices of the firms in the non-competitive sector is 1.96 percent higher than the growth of the PPI index over the post-privatization period. Interestingly, prices in the non-competitive sector fall in eight out of the 16 cases. ${ }^{21}$ Prices in the competitive sector also rise at a very low rate. The median cumulative increase in prices of the competitive sector is 1.27 percent higher than the growth of the PPI index over the post-privatization period.

We also employ two objective criteria of market power to confirm the result that changes in profitability are not driven by market power. The first objective criterion classifies an industry as competitive if it has at least 10 firms in it. Under the second objective criterion, a firm falls into the competitive group if its market share of the domestic market is less than 10 percent at the time of privatization. Relying on the number of firms as a proxy for market power is standard practice in the empirical literature. Classifying firms according to their market share is less common. ${ }^{22}$ The two advantages of using market share are to acknowledge that privatized firms are often large relative to members of their industry and to allow a role

${ }^{21}$ The following eight firms in the non-competitive sector experience decreases in prices relative to the PPI index: (1) Altos Hornos (steel, -24.5 percent), (2) Astilleros Unidos Ensenada (shipbuilding, -33 percent), (3) Dina Camiones (trucks , -62 percent), (4) Tabamex (Tobacco products, -65 percent); (5) Telefonos de Mexico (telephone services, -17 percent), (6) Tereftalatos de Mexico (chemicals, -41 percent); (7) Torres Mexicanas (electricity towers, -19.8 percent); and (8) Transportacion Maritima Mexicana (maritime transportation,-7.1 percent).

${ }^{22}$ We settle for market shares and not for a Herfindahl index because we lack data on market shares for private competitors of SOEs. 
for imports.

Results for the two objective measures of market power are presented in Panels B and C of Table VI. They confirm our previous finding: improvements in operating-income are greater in the competitive sector than in the non-competitive one. The opposite is true for improvements in net-income. With one exception (net-income-to-sales in the classification based on the number of firms), the differences between the competitive and non-competitive sectors are not statistically significant.

The two objective classifications of market power point to a surprising behavior in prices. Not only does the growth in prices in the non-competitive sector lag behind that of the competitive sector but prices in the non-competitive sector fall (in real terms). For example, the growth of prices in the competitive sector is 8.3 percentage points than in the non-competitive sector according to the market share criterion --the result is significant at 10 percent-- (Table VI.C). As it turns out, the behavior of prices in our sample is heavily influenced by nineteen firms in the food industry as that sector was subject to extensive price controls in the pre-privatization period and subsequently experienced relatively large price increases. Excluding the food sector from the sample yields a very different picture of the behavior of prices in the competitive sector without significantly altering our previous results on the behavior of the non-competitive sector. Interestingly, once we exclude the food sector, prices in the competitive sector fall according to all three criteria of market power. ${ }^{23}$ This finding is consistent with the prediction of the political view that SOEs will charge prices below marginal cost for goods that, like food, are consumed by large numbers of voters. ${ }^{24}$ However, we do not stress this result because of the small size of our sample.

The most salient result on Table VI is not one about changes in profitability but rather one about changes in operating efficiency as measured by cost-per-unit. Specifically, all three market power criteria show greater reductions in cost-per-unit in the non-competitive sector than in the competitive one. To illustrate, under the number of firms criteria, the median reduction in cost-per-unit is 23.62 percentage points in the non-competitive sector and 12.55 percentage points in the competitive sector (the difference is statistically significant at 1 percent). The remarkable feature about Table VI is how few statistically significant

\footnotetext{
${ }^{23}$ Prices in the competitive sector decline by 9.3 percent when firms are classified according to the prospectus criterion and by approximately 4.9 percent when the classification is based on objective criteria.

${ }^{24}$ The case of food illustrates the difficulties of pursuing the implications of the political model for the competitive and non-competitive sectors. Other things being equal, the political model predicts that the level of political interference in the firm will decline with the level of product market competition since the cost of political interference rises with market competition. In practice, however, the political benefits associated with interfering in some competitive sectors --such as food and consumer goods-- may result in large distortions. We are unable to test the predictions of the political model for the competitive and non-competitive sectors because the task requires knowledge of the political payoffs of interfering in the various sectors of the economy.
} 
differences exist in the behavior of the competitive and non-competitive sectors. Both sectors follow similar investment policies and experience similar rates of growth in sales. There is some evidence that layoffs in the competitive sector are larger than in the non-competitive sector but these differences are statistically significant only under one of the criterion -- that of the prospectus.

To summarize, the evidence thus far is not consistent with the view that monopoly power plays an important role in explaining the increased profitability of privatized firms. We find no evidence to support the view that the improved profitability is unique to the non-competitive sector. In fact, we cannot reject the hypothesis that both the competitive and non-competitive sectors experience identical improvements in profitability. We find no evidence that firms in the non-competitive sector increase their prices in real terms after privatization. Perhaps more interestingly, the similarity in the behavior of the competitive and noncompetitive sectors extends beyond profitability to include productivity growth --as measured by sales per employee--, investment policies, and growth in sales. The similarity in the restructuring behavior of the competitive and non-competitive sectors is inconsistent with the social view of SOEs which predicts higher profitability, lower growth in employment, lower investment and lower growth in sales in the noncompetitive sector than in the competitive one as monopolies shrink the scale of their operations in order to maximize profits.

\section{The Role of Transfers from Workers to Shareholders}

So far our discussion has focused on market power. In this section, however, we pause to consider if cuts in labor costs can explain the large gains in profitability that we documented in previous sections (redistribution hypothesis). Since labor costs often make up a large fraction of total costs, reductions in labor expenditures can potentially be the driving force behind the observed large increases in post-privatization profitability. Savings in labor costs could be expected if the wages of SOEs' workers exceed the marginal product of their work. Such savings can take a variety of forms including wage cuts, reductions in benefits and layoffs. In this section we try to quantify the contribution of layoffs and wage cuts to the observed changes in profitability.

Examining changes in wages is a natural way to test competing hypotheses regarding the channels through which privatization results in higher profitability. The possibility that SOE's workers may have been overpaid is not only consistent with political models of state ownership but, rather, it is implied by such modcls. It is prcciscly because wages in SOEs are excessive that jobs in these firms are coveted and come to represent valuable ways of rewarding loyal constituencies. Wages are predicted to rise (fall) in the post- 
privatization period if the efficiency gains that result from the depoliticization of the privatized firm are larger (smaller) than the quasi-rents that accrue to labor in the pre-privatization period. Therefore, the predictions of political models regarding changes in real wage are ambiguous. ${ }^{25}$ On the contrary, the redistribution hypothesis predicts that wages should fall or, at best stagnate, as the gains in profitability that we observe in the post-privatization period are best explained as transfers from workers to shareholders. In the redistribution view, pre-privatization wages may have exceeded market levels as a result of incomedistribution goals or policies that sought to cure failures in the labor market.

Contrary to the predictions of the redistribution hypothesis, wages increase substantially for the 101 firms in our sample for which data is available (Table VII). The mean (median) wage increases from $\mathrm{N} \$ 15,074(\mathrm{~N} \$ 9,992)$ in the pre-privatization period to $\mathrm{N} \$ 27,079(\mathrm{~N} \$ 22,481)$ in 1993. These large increases in real wages of the privatized firms in our sample are all the more surprising because overall real wages throughout Mexico stagnated during our sample period. Interestingly, gains by blue collar workers are larger than gains by white collar workers. The mean index of blue collar wages rises, relative to economy-wide wages, from 100 during the pre-privatization period to 275.43 in 1993 . Over the same period, however, the mean index of white collar workers rises, relative to economy-wide wages, from 100 to 177.99 .

All the competing hypothesis regarding SOEs that we have discussed so far in this section (i.e, the redistribution, social and political views), agree in predicting that layoffs will take place in the postprivatization period. Section 3 has already documented large cuts in employment. Thus, the fraction of the observed changes in profitability that can be attributed to layoffs is the issue that remains to be addressed. To provide an estimate of the cost savings due to layoffs we assume that the marginal product of all fired workers is zero and ask the counterfactual question of how much lower would profits had been if all the fired workers had been retained by the firm at their old wage. Specifically, we compute savings due to layoffs as follows:

$$
\text { Contribution of Layoffs }=\text { Wage }_{\text {pre }} * \frac{L_{\text {pre }}-L_{1993}}{\text { Sales }_{1993}}
$$

where Wage $e_{\text {pre }}$ is the average wage in the four years that precede privatization; $L_{\text {pre }}$ is the average number of employees in the four years that precede the privatization; $L_{1993}$ is the level of employment in 1993; and

${ }^{25}$ The managerial view is silent on the behavior of wages and employment. Ex-ante there is no reason to think that bad incentives for managers of SOEs are more likely to result in too much employment rather than too little. 
Sales $_{1993}$ are net sales in 1993.

As it turns out, savings due to layoffs are small relative to layoffs for two reasons: (1) total wages represent only 23.38 percent of sales in the pre-privatization period as wages tend to be low in Mexico; and (2) labor costs are spread over a much wider base since sales increase by 60 percent on average. The mean (median) savings from layoffs represent 6.80 (4.45) percent of sales in 1993. In contrast, the mean (median) operating-income-to-sales increases 24.11 (12.08) percentage points from -15.46 percent to 8.65 percent (2.73 percent to 9.35 percent). Accordingly, savings due to layoffs account for roughly one-third of the observed gains in profitability.

Increased productivity is probably not the only reason why wages rise after privatization. Wage increases may mirror changes in the composition of the workforce. In our sample, new hires are probably too small to account for large changes in the composition of the workforce. ${ }^{26}$ Large employment declines are a more serious concern as they may create the appearance of wage increases if firms disproportionately fire low-wage workers after privatization. To examine fully the role of changes in the composition of labor in the post-privatization period requires detailed wage data on laid-off employees which we do not have. However, we can test the robustness of our findings on wage gains to the impact of large reductions in employment by examining the behavior of wages in the sub-sample of firms that did not layoff employees. Panel B of Table 7 describes the wages paid by firms that increased their employment level in the postprivatization period. For example, firms that expand their employment levels increase the average wages per worker by 105.9 percent (from $\mathrm{N} \$ 12,727$ to $\mathrm{N} \$ 26,203$ ). In contrast, Panel $A$ shows that the corresponding number for the whole sample is 79.6 percent (from $\mathrm{N} \$ 15,074$ to $\mathrm{N} \$ 27,079$ ). We conclude that wage increases do not seem to be driven by sharp reductions in employment but rather reflect productivity gains.

To summarize, real wages experience large increases in the post-privatization period. Unfortunately, we lack data on benefits and it may have been benefits, rather than wages, that were cut. Taken at face value, however, these wage increases are consistent with the catching-up story that we have stressed in previous sections. Overall, the high level of labor redundancy in the pre-privatization period and the productivity gains in the post-privatization period are consistent with the political view. In contrast, the data is not consistent with the prediction of the redistribution hypothesis that wages should decline, or at best, stagnate. That is not to say that transfers from workers to shareholders do not play a role in explaining the success of privatization. On the contrary, savings due to layoffs account for roughly one-third of the change in

\footnotetext{
${ }^{26}$ The median percentage of 1993 employees hired in the post-privatization period is only 13 percent.
} 
profitability that takes place in the post-privatization period. We cannot say whether workers as a group suffered as a result of privatization since the answer depends on the post-privatization wage received by fired workers in their new occupations and on the weight given to the gains in income of the workers that were not fired.

\section{Privatization and Restructuring: Regression Analysis}

In this section we analyze the role that market power and deregulation play in determining privatization outcomes, as measured by our performance ratios. The results presented in Table VI are consistent with the view that market power is not an important factor in explaining the increased profitability of privatized firms. Regressions, however, may shed new light on the role of market power becausc Table VI does not take into account the length of time that the firm has been privately owned, for example. As it turns out, firms in noncompetitive sectors were, on average, privatized later and may have had less time to restructure.

The role of regulation is the second issue that we want to address. Previous research on regulation in connection with privatization has focused almost exclusively on the regulation of natural monopolies and public utilities. The telephone monopoly is the only utility in our sample. Rather than focus on natural monopolics, we take a different approach to regulation. We are interested in dercgulation as a potential complement to privatization for the oligopolistic but structurally competitive industries that dominate our sample. We loosely define the word deregulation to mean the removal of distortionary regulations. There are two ways in which deregulation complements privatization through the promotion of product market competition. At the most basic level, product market competition provides a tool to weed out the least efficient firms. The exit of inefficient firms may take very long if regulation inhibits new entry or makes exit costly. Deregulation may also complement privatization by raising the cost of political intervention in the privatized firm. Whereas an inefficient monopoly can squander its rents without endangering its existence, an inefficient firm in a competitive industry would have to receive a subsidy in order to stay afloat. In fact, competition often is restricted precisely because it raises the costs of political influence. The reverse side of this argument is that politicians may threaten to remove distortionary regulation in order to coerce firms to comply to their wishes (e.g., banks may be induced to allocate credit to sectors favored by politicians).

In Mexico, as in many other countries, privatization was coupled with deregulation policies aimed at increasing the role of market forces in the economy. In 1983, the beginning of our sample period, price controls were almost universal. Imports were severely restricted and, with a few exceptions for necessities, 
operated on an import license basis. Limits on foreign direct investment (FDI) were pervasive: foreign majority ownership of local firms was ruled out and many sectors were placed off-limits to foreigners. Over the course of our sample period, regulations were relaxed as a result of both an ideological shift and of government efforts to join GATT, NAFTA and the OECD.

The evolution of deregulation in Mexico can be traced through our sample as well. In 1983, all firms in our sample were sheltered from foreign imports by quotas and import licenses. Without exception, the prices of the goods they sold were set by the government who, in twenty-three cases also set output quotas. Finally, foreigners were excluded from participating in all the sectors in which the SOEs in our sample operated. The regulatory environment was quite different at the end of our sample period. Restrictions on prices and quantities had been lifted for 114 firms in our sample (68 percent of all observations), trade barriers were removed in 111 cases ( 65 percent of all observations), and foreign majority ownership was allowed in 131 cases ( 77 percent of all observations).

Chemicals, mining and air transportation are examples of sectors that remained restricted for foreigners in 1993. Trade barriers were found in the automobilc, auto parts, milk and sugar industries. Finally, price controls were common for food products, such as canned fish, sugar and sodas. In practice, price/quantity controls often co-exist with trade barriers (the correlation is 0.62 , significant at the 1 percent level). Price and quantity controls are associated with fewer restrictions on foreign ownership (the correlation is -0.32 , also significant at the 1 percent level). Perhaps surprisingly, there is almost no correlation $(-0.02)$ between restrictions on trade and restrictions on foreign direct investment.

We measure restructuring by evaluating changes in the industry-adjusted performance ratios presented on Table IV. We are interested in asking questions such as: Do firms in oligopolistic sectors catch up faster to firms in the same industry than firms in competitive sectors? Can deregulation serve as a complement to privatization by speeding the convergence of newly privatized firms to industry benchmarks? In practice, our industry control groups are often formed by publicly traded firms, resulting in rough industry benchmarks. We believe that industry-adjusted changes, albeit imperfect, are superior to raw changes as measures of restructuring.

To analyze the impact of deregulation, we define three variables: (1) a dummy variable that has a value of one if the price or quantity of the goods produced by the firm was set by the state in 1993, as price/quantity controls can distort the optimal output choice and may facilitate the continuation of political interference in the firm; (2) a dummy that takes value of one if barriers to foreign trade, such as import quotas or licenses, sheltered the privatized firm in 1993, as free trade increases competition in the final 
product market and allows for a richer variety of intermediate inputs; and (3) a dummy variable that takes the value of one if foreign ownership could not exceed 49 percent in 1993, as restructuring requires physical and human capital and foreigners may act as suppliers of both of them in Mexico.

We include several control variables in all our regressions. First, we control for year of privatization by including time-effects for each of the nine privatization cohorts. Second, we include controls for various company characteristics, such as: (1) a dummy variable that takes value of one if the firm produces nontradeable goods; (2) the number of strikes experienced by the SOE in the five years preceding privatization, as a measure of the strength of the union; (3) a dummy variable equal to one if the buyer is an outsider to the industry; and (4) the level of the appropriate industry-adjusted ratio in the year before privatization, as a measure of the scope for catching-up.

The results presented in Table VIII show that the pre-privatization gap with the private sector is the most important of all our control variables. The estimated coefficient on the gap in profitability with the private sector for both the operating-income-to-sales, the net-income-to-sales, and the cost-per-unit regressions are not statistically different from -1 . These findings confirm the convergence result documented in Table V. They show that by 1993 privatized firms mean-revert fully to the average profitability of the industry in which they operate. The results are consistent with the view that a large portion of the restructuring that we observe in the post-privatization period represents catching-up with more efficient peers in the private sector. The other interesting result regarding our control variables is that bad labor relations, as proxied by the number of strikes in the pre-privatization period, slow down restructuring.

The next issue we want to focus on is the role of the industry structure in post-privatization outcomes. To save space, we present only results based on regressions that include a dummy variable that takes the value of one if the privatization prospectus describes the industry as either monopolistic or oligopolistic and zero otherwise. Results are similar if we classify firms into groups based on either the number of firms in the industry or the market share of the privatized firm. The second and third columns of Table VIII, show that although both operating-income-to-sales and net-income-to-sales increase slightly more in the noncompetitive sector than in the competitive one (by 2.40 and 3.77 percentage points, respectively), the difference is not statistically significant (the $t$-statistics are 0.39 and 0.41 , respectively). The table also shows that while the investment activity and productivity growth of firms in the non-competitive sector match those of firms in the competitive sector, non-competitive firms undergo (statistically significantly) larger increases in sales and smaller reductions in employment than competitive ones.

To summarize our results on market power thus far, the data simply does not support the view that all 
that firms in the non-competitive sector need to do to increase profitability after privatization is to raise prices and lower quantities. Moreover there is no evidence indicating that market power plays a role in explaining the large changes in observed profitability. Rather, as attested by productivity growth, all privatized firms undergo substantial restructuring and there is no evidence suggesting that firms in noncompetitive sectors do any less of it.

The complementary nature of privatization and deregulation is the last issue we want to focus on. We do not include all three regulation variables simultaneously because trade barriers and price/quantity controls are highly correlated. Instead, we report results based on including FDI and price/quantity controls and briefly discuss results based on including FDI and trade barriers (not shown). The results of the first specification in Table VIII support the view that deregulation is associated with better post-privatization performance. For example, controlling prices/quantities has a large negative impact on changes in profitability as it subtracts 11.54 percentage points to mean changes in operating-income-to-sales and 21.26 percentage points to mean changes in net-income-to-sales (both of these changes are statistically significant). The negative impact of price/quantity controls is not only confined to profitability changes. More importantly, price and quantity controls are also associated with smaller gains in operating efficiency. This can be seen in the form of smaller reductions in cost-per-unit and slower growth in labor productivity. These price and quantity restrictions are also associated with smaller reductions in employment and lower levels of investment. Not surprisingly, controlled prices are associated with higher growth in sales as lower prices stimulate sales.

Liberalizing foreign investment has a much weaker impact on restructuring. The only statistically significant result is that there is an association between restrictions on FDI and higher industry-adjustedinvestment-to-fixed-assets ratios. Moreover, restrictions on FDI have no effect on unadjusted-investment-tofixed-assets ratios (we do not report the results of regressions on unadjusted ratios). A possible reason why FDI-restrictions facilitate catching up with the private sector is that firms that operate in FDI restricted sectors have low investment-to-fixed-assets. Restrictions on FDI are also associated with lower increases in industry-adjusted costs-per-unit. This last result is obtained although FDI restrictions are associated with larger changes in costs-per-unit at the firm level (again, we do not report the unadjusted regressions), suggesting that FDI facilitates catching up by lowering the industry benchmark.

We also tested--but do not report--an alternative specification of the regression presented in Table VIII that substitutes price/quantity restrictions for trade barriers. The results of the second specification are very similar to those of the first which may not be surprising given the high correlation between price/quantity 
restrictions and trade barriers. The only noteworthy difference between the first and second specifications is that cost-per-unit is 19.6 percentage points higher in sectors with trade barriers than sectors without trade barriers. This last result suggests that the elimination of trade barriers speeds up restructuring not only by eliminating distortions from the product market but also by improving the choice of intermediate inputs.

The findings of this section can be summarized as follows: the observed changes in the performance of privatized firms are the result of catching-up and not of the exploitation of market power. Deregulation -particularly the removal of price/quantity controls and trade barriers-- is associated with faster convergence to industry benchmarks. Our results remain tentative to the extent that limits on data availability make our control groups somewhat coarse.

\section{Conclusion}

The social and agency views represent two different perspectives on the role of SOEs and privatizations. Elements of each view are likely to be present in any economy. Accordingly, the interesting question is what is the contribution of improved incentives and the depoliticization of the firm to the observed increases in post-privatization profitability and what fraction of those profits comes at the expense of the rest of the society. Losses to society as a result of privatization may come from a multiplicity of sources ranging from higher pollution to lack of access to public services for individuals residing in remote localities when those services are placed under private ownership. In this paper we have focused on what are, perhaps, the two most likely channels for social losses: (1) increased prices as firms capitalize on their market power; and (2) layoffs and lower wages as firms seek to renegotiate generous labor contracts.

We find evidence of large increases in profitability as a result of privatization. For example, operatingincome-to-sales raises by 24 percentage points in the post-privatization period. We estimate that price increases are responsible for roughly 10 percent of the increase in post-privatization profitability. Price increases do not appear to be linked to monopolistic power. We find that, following privatization, firms undergo a harsh restructuring process and do not simply add a markup to their marginal costs as the market power hypothesis would predict. Rather, sales increase quickly in the post-privatization period although the stock of fixed assets remains basically unchanged and the number of workers falls sharply. This increased efficiency of privatized firms translates into large gains in profitability. The large increases in operatingincome-to-sales and net income-to-sales ratios effectively illustrate this point. "Catching-up" is probably the best "one-word" description of our results as privatized firms quickly converge to industry standards as it becomes difficult to distinguish them from industry-matched control groups or exchange-traded private 
firms .

The conclusion that arises from our various attempts to tease out the differences in post-privatization outcomes between the competitive and non-competitive sector is that their behavior is remarkably similar. Specifically, we cannot reject the hypothesis that both the competitive and non-competitive sectors experience identical improvements in profitability. Similarly, there is no evidence that, in the postprivatization period, price increases in the non-competitive sector are larger than in the competitive one. The similarity in the behavior of the competitive and non-competitive sectors extends beyond profitability to include productivity growth, investment policies, and growth in sales. We find no evidence to support the predictions of the market power hypothesis of higher profitability, lower growth in employment, lower investment and lower growth of sales in the non-competitive sector than in the competitive one as oligopolies shrink the scale of their operations in order to maximize profits.

Transfers from laid-off workers are an important source of increased profitability representing 33 percent of the gains in operating income. Interestingly, workers who stay with the firm receive large increases in real wages: the mean blue collar wage rises from $N \$ 9,525$ to $N \$ 22,425$ while the mean white collar wage rises from $N \$ 27,992$ to $N \$ 44,301$. These large increases in post-privatization wages support the view that productivity gains are the dominant factor in post-privatization outcomes. We attribute to productivity gains the fraction of the increases in operating income not accounted for by higher prices and layoffs (equal to 57 percent). Our estimate of productivity gains may be too optimistic if other channels for transferring value from society to privatized firms are quantitatively important. Be as it may, transfers from society to the firm are partially offset by taxes which absorb a little over half the gains in operating income. To summarize, redistribution plays a role but is not the whole story. Our data supports models that emphasize the inefficiency of SOEs, in particular those that highlight their reliance on excessive employment, but does not support models that emphasize the role of market power.

Deregulation often accompanies privatization. This paper presents the first empirical estimates of the importance of the interaction between privatization and deregulation. We find that deregulation -particularly the removal of price/quantity controls and trade barriers-- is associated with faster convergence to industry benchmarks. Governments often spend substantial energies in restructuring to-be-privatized firms and in designing optimal auction rules. Lopez-de-Silanes (1997) shows that these efforts often destroy value. These findings support privatization policies that stress speed and facilitate product market competition.

The picture that emerges from our study of privatization in Mexico is one in which some job losses were 
almost inevitable given the high level of excess capacity (both employees and physical capital) under which SOEs operated before they were sold. Nevertheless, it is tempting to ask whether the social gains from privatization were large enough to offset job losses. Of course, it is impossible to answer the question without knowing the fate of laid-off employees and making assumptions about the weight that their loss receives in the social welfare function. However, we believe that the following calculation suggests that the additional revenue received by the government as a result of the privatization was probably large enough to --at least in principle-- offset society's cost of job losses. The increased government revenue includes the $\mathrm{N} \$ 186$ million (US\$60 million) raised by the average privatization auction. In addition, government revenues were further boosted by increased tax collections. We estimate that the present value of the increased tax collections is roughly $\mathrm{N} \$ 177$ million (US\$57 million) under the assumption that the $\mathrm{N} \$ 26.4$ million (US\$8.5 million) in higher taxes that we find in our sample can be treated as a perpetuity and discounted at a 15 percent rate. The additional revenues that resulted from privatization would have been enough to give $\mathrm{N} \$ 659,454$ (US\$212,727) to each of the 550 laid-off workers from the average firm --a very large sum given that the annual pre-privatization income of an average SOE worker is $N \$ 14,880(\mathrm{US} \$ 4,800)$.

\section{References}

Armstrong, Mark, Simon Cowan, and John Vickers, Regulatory Reform: Economic Analysis and British Experience, The MIT Press, Cambridge, Massachusetts, 1994

Donahue, John D., The privatization decision, Basic Books, New York, 1989.

Caves, Richard E., Lessons From Privatization in Britain: State Enterprise Behavior, Public Choice, and Corporate Governance, Journal of Economic Behavior and Organization, 145-169, 1990.

Galal, Ahmed, Leroy Jones, Pankaj Tandon, and Ingo Vogelsang, Welfare Consequences of Selling Public Enterprises: An Empirical Analysis, Oxford University Press, New York, 1992.

Kahn, Alfred E., The Economics of Regulation. Principles and Institutions, The MIT Press, Cambridge, Massachusetts, 1988.

Kikeri, Sunita, John Nellis, and Mary Shirley, Privatization: The Lessons form Market Economies, The World Bank Research Observer 9, 241-272, 1994.

Laffont, Jean Jacques, and Jean Tirole, $A$ Theory of Incentives in Regulation Procurement, The MIT Press, Cambridge, Massachusetts, 1993.

Lopez-de-Silanes, Florencio, Determinants of Privatization Prices, Quarterly Journal of Economics, 
November 1997.

Lopez-de-Silanes, Florencio and Guillermo Zamarripa, Deregulation and Privatization of Commercial Banking: Pre- versus Post-Performance, Revista de Analisis Economico, 1996.

Lustig, Nora, Mexico: The Remaking of an Economy, The Brookings Institution, Washington, DC, 1992. Megginson, William L., Robert C. Nash, and Mathias van Randerborgh, The Financial and Operating Performance of Newly Privatized Firms: An International Empirical Analysis, Journal of Finance, XLIX, 403-452, 1994.

Shapiro, Carl, and Robert Willig, Economic Rationales for the Scope of Privatization, In The political Economy of Public Sector Reform and Privatization (ed. E. N. Suleiman and J. Waterbury), Westview Press, London, 55-87, 1990.

Shleifer, Andrei and Robert W. Vishny, Politicians and Firms, Quarterly Journal of Economics, 1994.

Stigler, George J., The Theory of Economic Regulation, in Bell Journal of Economics and Management Science, II, pp. 3-21, 1971.

Vickers, John and George Yarrow, Privatization: An Economic Analysis, The MIT Press, Cambridge, Massachusetts, 1988.

Vining, Aiden and Anthony Boardman, Ownership vs. Competition: Efficiency in Public Enterprise, Public Choice, LXXII, 205-239, March 1992

World Bank, Bureaucrats in Business: The Economics and Politics of Government Ownership, Oxford University Press, New York, 1995. 


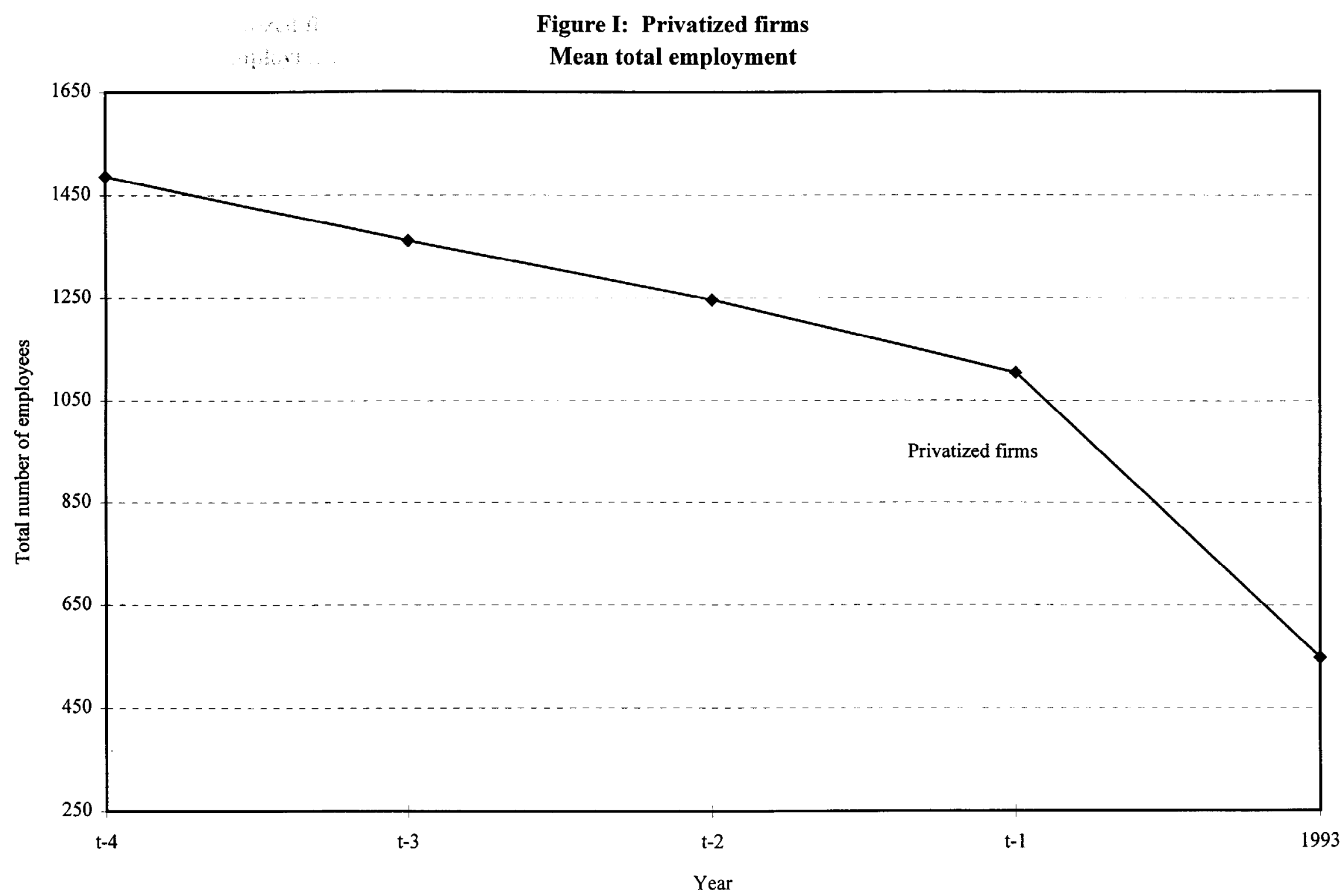




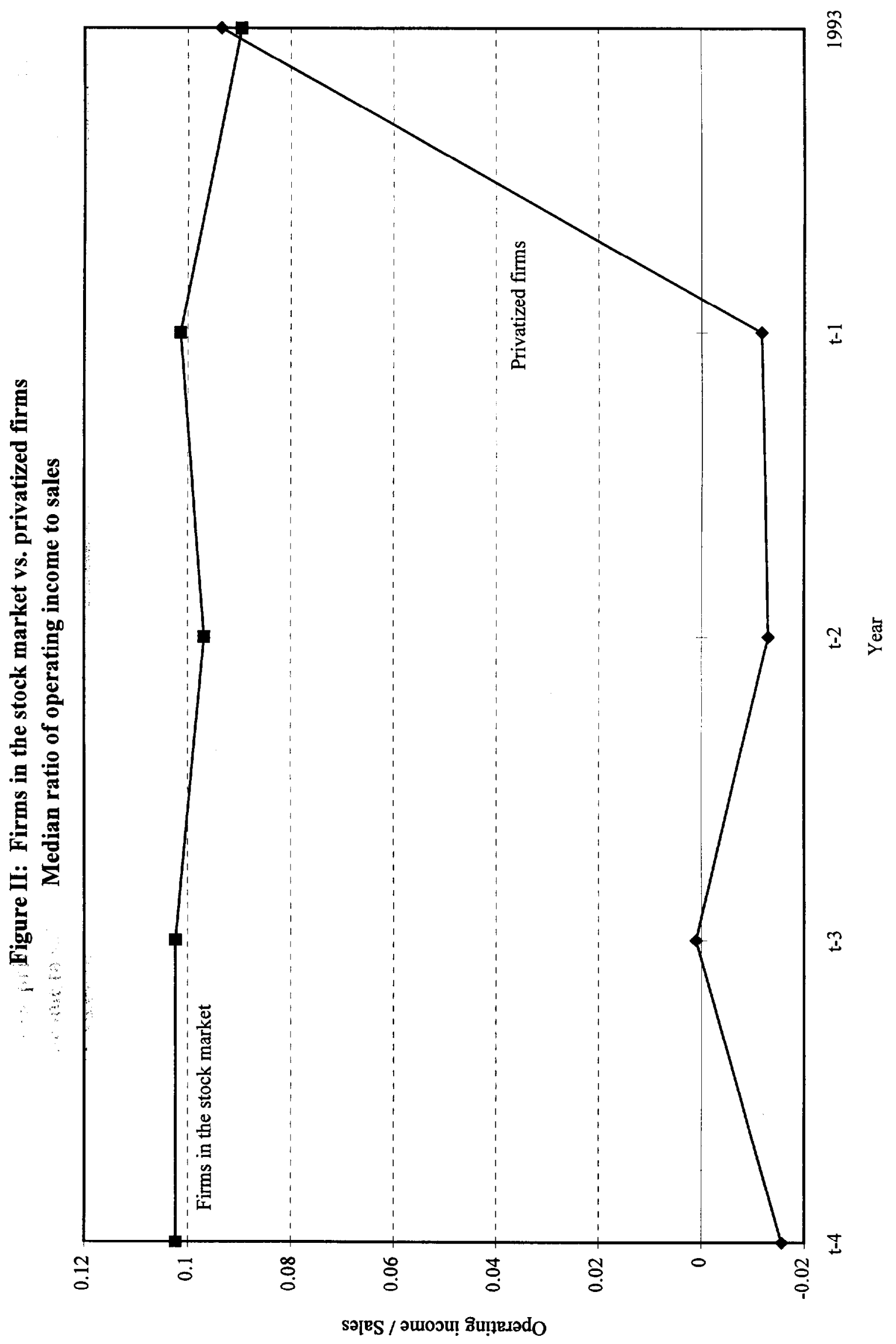


Figure.III: Firms in the stock market vs. privatized firms

Median ratio of net income to sales

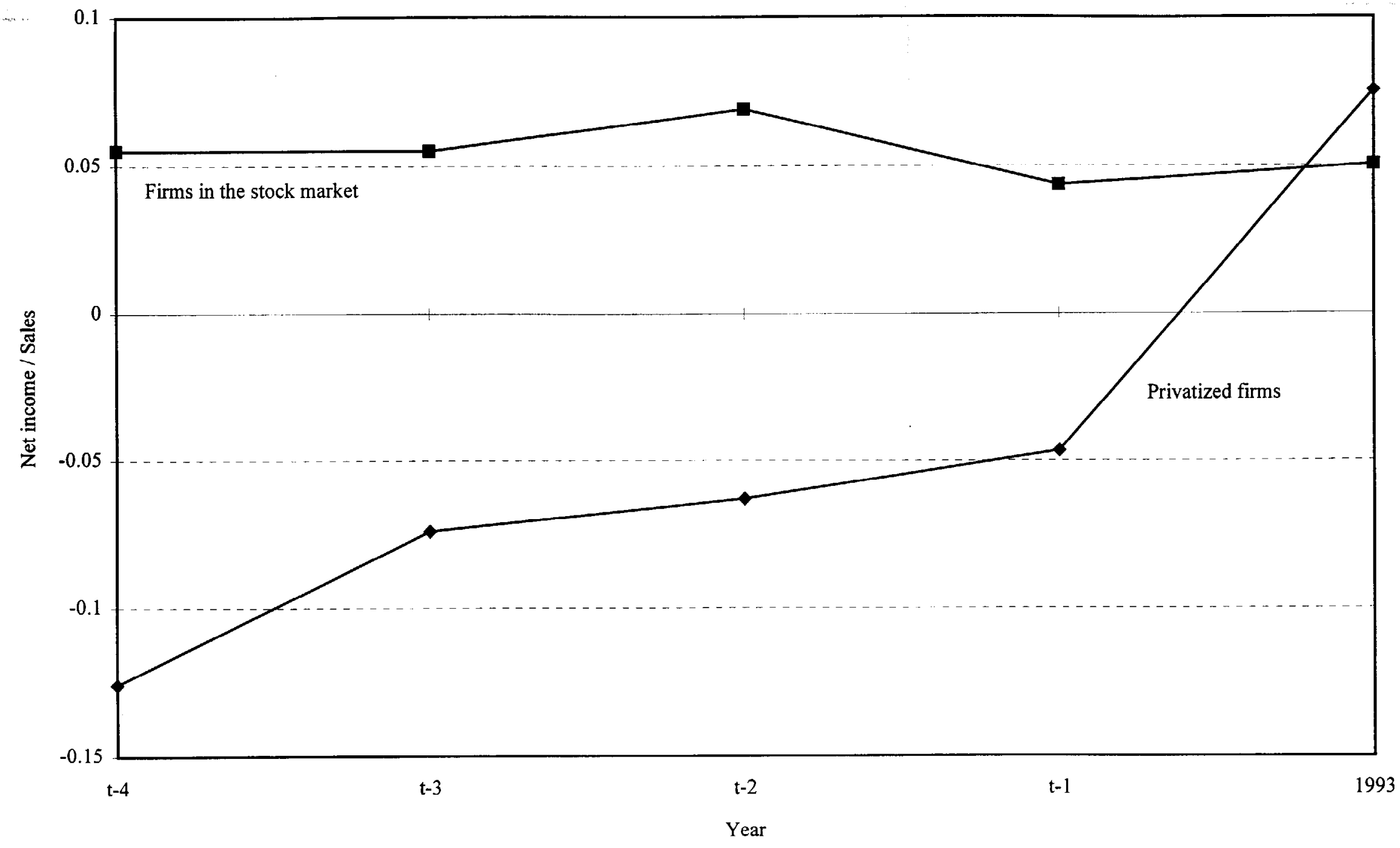




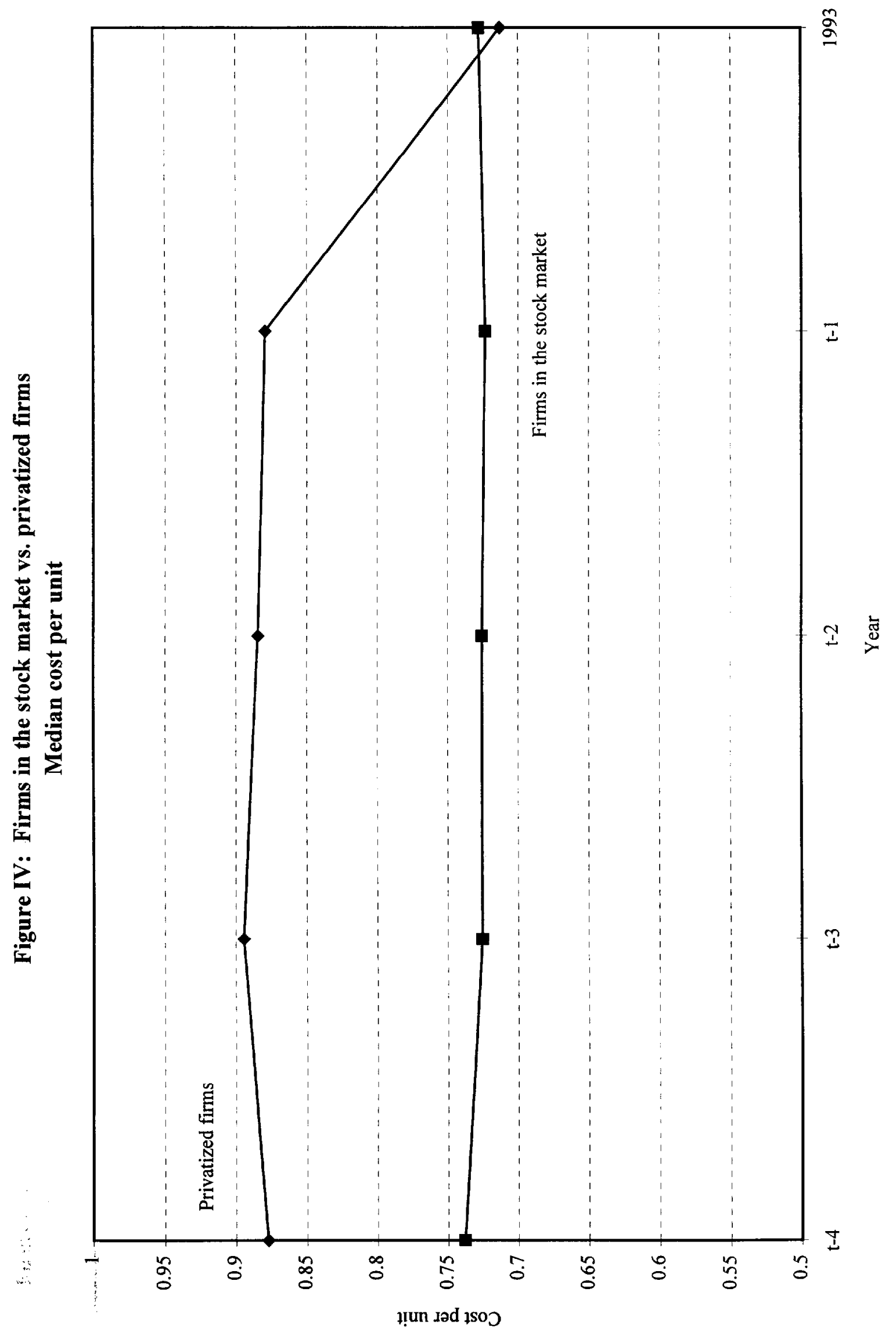




\section{Table 1}

\section{Privatization Contracts According to Four Digit Industry Classification}

This table classifies privatization contracts across industries. The table indicates for each industry: (1) the number of contracts signed; (2) the ratio of the pre-privatization value of the industry's total divested assets to the total preprivatization value of all the assets in the sample; and (3) the ratio of the industry's pre-privatization total employment to the total pre-privatization employment of the firms in the sample.

\begin{tabular}{|c|c|c|c|}
\hline Industry & $\begin{array}{l}\text { Number of } \\
\text { Contracts }\end{array}$ & $\begin{array}{l}\text { \%Assets in the } \\
\text { Sample }\end{array}$ & $\begin{array}{l}\text { \%Labor in the } \\
\text { Sample }\end{array}$ \\
\hline \multicolumn{4}{|l|}{ I. Mining } \\
\hline Mining of Metallic Minerals & 6 & 0.0853 & 0.0389 \\
\hline Mining of Non-Metallic Minerals & 6 & 0.0083 & 0.0105 \\
\hline \multicolumn{4}{|l|}{ I. Manufacturing } \\
\hline Milk Products & 4 & 0.0015 & 0.0145 \\
\hline Fruits and Vegetables & 4 & 0.0003 & 0.0025 \\
\hline Canned Fish and Seafood & 12 & 0.0060 & 0.0191 \\
\hline Grains and Oils & 9 & 0.0105 & 0.0209 \\
\hline Sugar Mills & 44 & 0.0510 & 0.1699 \\
\hline Animal Foods & 8 & 0.0016 & 0.0034 \\
\hline Beverages & 2 & 0.0005 & 0.0033 \\
\hline Tobacco Products & 3 & 0.0020 & 0.0110 \\
\hline Textiles, Clothing and Leather & 7 & 0.0061 & 0.0145 \\
\hline Wood and Wood Products & 2 & 0.0005 & 0.0020 \\
\hline Paper and Printing & 5 & 0.0104 & 0.0241 \\
\hline Chemicals, Oil Products and Plastic & 23 & 0.0659 & 0.0376 \\
\hline Non-Metallic Mineral Products & 9 & 0.0084 & 0.0145 \\
\hline Basic Metals and Derivative Products & 22 & 0.2224 & 0.1672 \\
\hline Heavy Machinery and Equipment & 7 & 0.0040 & 0.0086 \\
\hline Electronics, Machinery and Equipment & 6 & 0.0130 & 0.0292 \\
\hline Automotive Industry & 15 & 0.0284 & 0.0469 \\
\hline Transportation Equipment & 2 & 0.0028 & 0.0109 \\
\hline \multicolumn{4}{|l|}{ III. Services } \\
\hline Hotels and Restaurants & 8 & 0.0054 & 0.0231 \\
\hline Land and Sea Transportation & 4 & 0.0233 & 0.0021 \\
\hline Air Transportation & 3 & 0.0819 & 0.1053 \\
\hline Communications & 1 & 0.3590 & 0.2178 \\
\hline Real Estate and Professional Services & 4 & 0.0017 & 0.0018 \\
\hline Recreation and Entertainment Services & 2 & 0.0000 & 0.0004 \\
\hline Total & 218 & 1.00 & 1.00 \\
\hline
\end{tabular}


Table 2

Observations in the Sample

This table describes the composition of our sample. Firms are broken down into four groups. For each classification we provide: (1) the number of firms; (2) the fraction of the pre-privatization value of total sales accounted for by the group's members; and (3) the fraction of the pre-privatization employment accounted for by the group's members.

\begin{tabular}{lcccc}
\hline \hline & Number & $\begin{array}{c}\text { \%Sales of the } \\
\text { Sample }\end{array}$ & $\begin{array}{c}\text { \%Assets of the } \\
\text { Sample }\end{array}$ & $\begin{array}{c}\text { \%Labor of the } \\
\text { Sample }\end{array}$ \\
\hline $\begin{array}{l}\text { Firms in our sample } \\
\begin{array}{l}\text { Merged and no longer keep independent } \\
\text { accounting records }\end{array}\end{array}$ & 170 & 97.31 & 97.17 & 92.10 \\
$\begin{array}{l}\text { Firms not found due to incomplete } \\
\text { census records, name changes, etc. }\end{array}$ & 26 & 0.17 & 0.35 & 0.48 \\
Liquidated firms & 13 & 1.69 & 1.56 & 5.22 \\
\hline Total & 218 & 100 & 100 & 2.20 \\
\hline \hline
\end{tabular}


Table 3: The Variables and Ratios Used on Tables 4 through 7

This table describes the quantitative variables collected for the 170 non-financial firms privatized in Mexico in the period $1983-1991$ and used to measure the performance of privatized firms. The first column gives the name of the variable or the ratio. The second column describes the item. Source: 1994 Economic Census from the Mexican National Statistics Institute (INEGI).

Depreciation

Total compensation

Employees

White-collar workers

Blue-collar workers

Sales

Operating expenses

Cost of sales

Operating income

PPE

Operating income/ Sales

Operating income/ PPE

Operating income/

Employees

Interest expenses

Extraordinary items

Direct subsidies

Net taxes paid

Net income

Net income/ Sales

Net income/ PPE

Log (Sales)

Log (Sales/PPE)

Log (Sales/Employees)

Log (PPE)
The reduction in taxable income due to the deterioration of a company's fixed assets (adjusted for relevant year's inflation rate).

Includes the value of wage and salary, any additional fringe benefits, and special services provided by employer.

The total number of workers (paid and unpaid) who depend directly on the companies. They receive, in general, either salary or wage payments on a regular schedule and work at least 15 hours a week. A minimal number of these workers do not receive a regular salary. This number includes all workers on strike, as well as workers who still report to officials of the company despite different work locations, and workers on sickleave or vacation. It does not include individuals who are retired or working on commission.

White-collar workers perform skilled labor and administrative tasks for modest to high salaries. They are individuals involved in sales, administration, and management.

Blue-collar workers perform un- or semi-skilled labor for modest to low wages. They perform tasks directly related to the (mass) production process or menial services. Typically, they are factory-line or maintenance workers.

Sales are equal to the total value of products and services sold, nationally and internationally, minus sales returns and discounts.

Operating expenses are equal to general selling and administrative expenses, plus the total compensation of white-collar workers.

Cost of sales is equal to the direct expense involved in the production of a good (or provision of a service). This includes raw material expenditure plus total compensation paid to blue-collar workers.

Operating income is equal to sales minus operating expenses, minus cost of sales, and minus depreciation. Property, plant and equipment is equal to the value of a company's fixed assets adjusted for inflation.

She ratio of operating income to sales. For each firm, we computed the pre-privatization value of this ratio by averaging its value in the four years that precede privatization. The post-privatization ratio is taken from information of the 1993 INEGI Census

The ratio of operating income to property, plant and equipment (PPE). For each firm, we computed the preprivatization value of this ratio by averaging its value in the four years that precede privatization. The postprivatization ratio is taken from information of the 1993 INEGI Census.

The ratio of operating income to total number of employees. For each firm, we computed the preprivatization value of this ratio by averaging its value in the four years that precede privatization. The postprivatization ratio is taken from information of the 1993 INEGI Census.

The cost of borrowed funds.

Gains or losses that both are unusual in nature and occur infrequently.

Value of government transfers paid to companies in the form of subsidy or tax exemptions.

Income taxes paid net of direct subsidies received during the fiscal year.

Net income is equal to operating income minus interest expenses and net taxes paid, as well as the cost of any extraordinary items.

The ratio of net income to sales. For each firm, we computed the pre-privatization value of this ratio by averaging its value in the four years that precede privatization. The post-privatization ratio is taken from information of the 1993 INEGI Census.

The ratio of net income to property, plant and equipment (PPE). For each firm, we computed the preprivatization value of this ratio by averaging its value in the four years that precede privatization. The postprivatization ratio is taken from information of the 1993 INEGI Census.

The log of sales. Its pre-privatization value corresponds to the average of the log of sales in the four years that precede privatization. The post-privatization value corresponds to the log of sales in 1993.

The log of the ratio of sales to property, plant and equipment (PPE). Its pre-privatization value corresponds to the average of the $\log$ of the ratio in the four years that precede privatization. The post-privatization value corresponds to the $\log$ of the ratio in 1993.

The $\log$ of the ratio of sales to total number of employees. Its pre-privatization value corresponds to the average of the $\log$ of the ratio in the four years that precede privatization. The post-privatization value corresponds to the log of the ratio in 1993.

The log of PPE. Its pre-privatization value corresponds to the average of the log of PPE in the four years that precede privatization. The post-privatization value corresponds to the log of PPE in 1993. 
Cost per unit

Log (Employees)

Log (White collar workers)

Log (Blue collar workers)

Investment Investment/ Sales

Investment/Employees

Investment/PPE

Log (PPE/Employees)

Net taxes/Sales

Index of real prices
The ratio of cost of sales to net sales. For each firm, we computed the pre-privatization value of this ratio by averaging its value in the four years that precede privatization. The post-privatization ratio is taken from information of the 1993 INEGI Census.

The $\log$ of the total number of employees. Its pre-privatization value corresponds to the average of the $\log$ of employees in the four years that precede privatization. The post-privalization value corresponds to the log of employees in 1993.

The log of the total number of white-collar workers. Its pre-privatization value corresponds to the average of the $\log$ of white collar workers in the four years that precede privatization. The post-privatization value corresponds to the $\log$ of white collar workers in 1993.

The $\log$ of the total number of blue-collar workers. Its pre-privatization value corresponds to the average of the log of blue-collar workers in the four years that precede privatization. The post-privatization value corresponds to the log of blue collar workers in 1993.

The value of expenditure to acquire property, equipment, and other capital assets that produce revenue. The ratio of investment to sales. For each firm, we compuled the pre-privatization value of this ratio by averaging its value in the four years that precede privatization. The post-privatization ratio is taken from information of the 1993 INEGI Census.

The ratio of Investment to total number of employees. For each firm, we computed the pre-privatization value of this ratio by averaging its value in the four years that precede privatization. The postprivatization ratio is taken from information of the 1993 INEGI Census.

The ratio of investment to PPE. For each firm, we computed the pre-privatization value of this ratio by averaging its value in the four years that precede privatization. The post-privatization ratio is taken from information of the 1993 INEGI Census.

The log of the ratio of PPE to tolal number of employees. Its pre-privatization value corresponds to the average of the log of the ratio in the four years that precede privatization. The post-privatization value corresponds to the log of the ratio in 1993.

The ratio of net taxes to sales. For each firm, we computed the pre-privatization value of this ratio by averaging its value in the four years that precede privatization. The post-privatization ratio is taken from information of the 1993 INEGI Census.

The Paasche price index is the ratio (expressed as a percentage) of the total value in the given year of the quantity of each commodity produced in the given year to what would have been the total value of these quantities in the base year. 
Table 4

Changes in Performance for the Sample of Privatized Firms

\begin{tabular}{|c|c|c|c|c|c|}
\hline Variable & $\mathrm{N}$ & $\begin{array}{l}\text { Mean Before } \\
\text { Median Before }\end{array}$ & $\begin{array}{l}\text { Mean After } \\
\text { Median After }\end{array}$ & $\begin{array}{l}\text { t-statistic for } \\
\text { change in Mean }\end{array}$ & $\begin{array}{l}\text { Z-statistic for } \\
\text { change in Median }\end{array}$ \\
\hline \multicolumn{6}{|l|}{ I. Profitability } \\
\hline Operating Income/Sales & 170 & $\begin{array}{l}-0.1546 \\
-0.0273\end{array}$ & $\begin{array}{l}0.0865 \\
0.0935\end{array}$ & $5.43^{\mathrm{a}}$ & $5.62^{\mathrm{a}}$ \\
\hline Net Income/Sales & 170 & $\begin{array}{l}-0.3632 \\
-0.1297\end{array}$ & $\begin{array}{l}0.0364 \\
0.0753\end{array}$ & $4.84^{\mathrm{a}}$ & $6.48^{\mathrm{a}}$ \\
\hline Operating Income/PPE & 170 & $\begin{array}{l}-0.1053 \\
-0.0142\end{array}$ & $\begin{array}{l}0.2397 \\
0.1305\end{array}$ & $4.38^{a}$ & $5.18^{a}$ \\
\hline Net Income/PPE & 170 & $\begin{array}{l}-0.2176 \\
-0.0728\end{array}$ & $\begin{array}{l}0.0537 \\
0.0839\end{array}$ & $2.59^{\mathrm{a}}$ & $5.82^{\mathrm{a}}$ \\
\hline \multicolumn{6}{|l|}{ II. Operating Efficiency } \\
\hline Cost per unit & 170 & $\begin{array}{l}0.9166 \\
0.8805\end{array}$ & $\begin{array}{l}0.7017 \\
0.7129\end{array}$ & $-6.68^{a}$ & $-6.95^{a}$ \\
\hline Log(Sales/PPE) & 170 & $\begin{array}{l}0.0570 \\
0.1680\end{array}$ & $\begin{array}{l}0.7034 \\
0.4065\end{array}$ & $4.25^{\mathrm{a}}$ & $3.64^{\mathrm{a}}$ \\
\hline Log(Sales/Employees) & 169 & $\begin{array}{l}4.3674 \\
4.2054\end{array}$ & $\begin{array}{l}5.4204 \\
5.1963\end{array}$ & $8.33^{\mathrm{a}}$ & $8.35^{\mathrm{a}}$ \\
\hline Operating Income/Employees & 169 & $\begin{array}{c}1.6709 \\
-0.6826\end{array}$ & $\begin{array}{l}54.1750 \\
14.4131\end{array}$ & $6.36^{\mathrm{a}}$ & $5.36^{\mathrm{a}}$ \\
\hline \multicolumn{6}{|l|}{ III. Labor } \\
\hline Log(Employees) & 169 & $\begin{array}{l}6.1655 \\
6.2976\end{array}$ & $\begin{array}{l}5.5166 \\
5.7301\end{array}$ & $4.37^{\mathrm{a}}$ & $4.35^{\mathrm{a}}$ \\
\hline Log(Blue Collar Workers) & 168 & $\begin{array}{l}5.8222 \\
5.9558\end{array}$ & $\begin{array}{l}5.2878 \\
5.3471\end{array}$ & $3.62^{\mathrm{a}}$ & $3.62^{\mathrm{a}}$ \\
\hline Log(White Collar Workers) & 169 & $\begin{array}{l}4.8367 \\
4.7875\end{array}$ & $\begin{array}{l}4.3015 \\
4.3241\end{array}$ & $4.17^{\mathrm{a}}$ & $4.36^{\mathrm{a}}$ \\
\hline \multicolumn{6}{|l|}{ IV. Assets and Investment } \\
\hline $\log (P P E)$ & 170 & $\begin{array}{l}10.5194 \\
10.4582\end{array}$ & $\begin{array}{l}10.2395 \\
10.5497\end{array}$ & -1.17 & 0.34 \\
\hline Investment/Sales & 170 & $\begin{array}{l}0.0299 \\
0.0022\end{array}$ & $\begin{array}{l}0.0449 \\
0.0125\end{array}$ & $1.77^{\mathrm{c}}$ & $4.13^{\mathrm{a}}$ \\
\hline Investment/Employees & 169 & $\begin{array}{l}3.1655 \\
0.1335\end{array}$ & $\begin{array}{c}10.3074 \\
2.7184\end{array}$ & $4.69^{\mathrm{a}}$ & $5.96^{\mathrm{a}}$ \\
\hline Investment/PPE & 170 & $\begin{array}{l}0.0244 \\
0.0040\end{array}$ & $\begin{array}{l}0.0718 \\
0.0256\end{array}$ & $4.50^{\mathrm{a}}$ & $5.36^{\mathrm{a}}$ \\
\hline Log(PPE/Employees) & 169 & $\begin{array}{l}4.4645 \\
4.2978\end{array}$ & $\begin{array}{l}4.6624 \\
4.8014\end{array}$ & 1.15 & $1.86^{\mathrm{c}}$ \\
\hline \multicolumn{6}{|l|}{ V. Output } \\
\hline Index of Real Prices (Paasche) & 83 & $\begin{array}{l}100.00 \\
100.00\end{array}$ & $\begin{array}{l}102.87 \\
101.27\end{array}$ & 0.76 & 1.58 \\
\hline \multicolumn{6}{|l|}{ VII. Net Taxes } \\
\hline Net Taxes/Sales & 170 & $\begin{array}{c}-0.0462 \\
0.0000\end{array}$ & $\begin{array}{l}0.0839 \\
0.0763\end{array}$ & $6.95^{\mathrm{a}}$ & $10.80^{\mathrm{a}}$ \\
\hline Net Taxes & 170 & $\begin{array}{l}-760.24 \\
0.0000\end{array}$ & $\begin{array}{c}25,684.12 \\
2,162.80\end{array}$ & $2.21^{\mathrm{b}}$ & $10.94^{*}$ \\
\hline
\end{tabular}


Table 5

\section{Industry-Adjusted Changes in Performance for the Sample of Privatized Firms}

This table presents industry-adjusted results for the sample of 170 privatized firms. The table presents, for each empirical proxy, the number of usable observations, the mean and median values of the proxy before privatization and the mean and median value for the proxy in 1993. We report t-statistics and z-statistics (Wilcoxon rank sum) as our test for significance for the change in mean and median values, respectively. Definitions for each variable can be found on Table 3.

\begin{tabular}{|c|c|c|c|c|c|}
\hline Variable & $N$ & $\begin{array}{l}\text { Mean Before } \\
\text { (Median) }\end{array}$ & $\begin{array}{c}\text { Mean After } \\
\text { (Median) }\end{array}$ & $\begin{array}{l}\text { t-statistic for } \\
\text { change in Mean }\end{array}$ & $\begin{array}{l}\text { Z-statistic for } \\
\text { change in Median }\end{array}$ \\
\hline \multicolumn{6}{|l|}{ I. Profitability } \\
\hline Operating Income/Sales & 168 & $\begin{array}{l}-0.2970 \\
-0.1353\end{array}$ & $\begin{array}{l}0.0262 \\
0.0177\end{array}$ & $4.30^{\mathrm{a}}$ & $7.15^{\mathrm{a}}$ \\
\hline Operating Income/PPE & 168 & $\begin{array}{l}-0.2324 \\
-0.1471\end{array}$ & $\begin{array}{l}0.0926 \\
0.0016\end{array}$ & $4.11^{\mathrm{a}}$ & $4.87^{\mathrm{a}}$ \\
\hline $\begin{array}{c}\text { Net Income/Sales } \\
\therefore:\end{array}$ & 168 & $\begin{array}{l}-0.4036 \\
-0.1720\end{array}$ & $\begin{array}{l}0.0091 \\
0.0388\end{array}$ & $4.65^{\mathrm{a}}$ & $6.99^{\mathrm{a}}$ \\
\hline Net Income/PPE & 168 & $\begin{array}{l}-0.2632 \\
-0.1494\end{array}$ & $\begin{array}{c}-0.0162 \\
0.0348\end{array}$ & $2.40^{\mathrm{a}}$ & $5.76^{\mathrm{a}}$ \\
\hline \multicolumn{6}{|l|}{ II. Operating Efficiency } \\
\hline Cost per unit & 168 & $\begin{array}{l}0.1825 \\
0.1423\end{array}$ & $\begin{array}{l}-0.0012 \\
-0.0104\end{array}$ & $-5.64^{a}$ & $-5.63^{a}$ \\
\hline Log(Sales/Employees) & 166 & $\begin{array}{l}-1.1921 \\
-1.3133\end{array}$ & $\begin{array}{l}-0.2562 \\
-0.4167\end{array}$ & $6.51^{\mathrm{a}}$ & $6.85^{\mathrm{a}}$ \\
\hline Log(Sales/PPE) & 168 & $\begin{array}{l}-0.2785 \\
-0.1449\end{array}$ & $\begin{array}{l}0.1912 \\
0.0501\end{array}$ & $3.11^{\mathrm{a}}$ & $2.35^{\mathrm{b}}$ \\
\hline \multicolumn{6}{|l|}{ III. Labor } \\
\hline Log(Employees) & 169 & $\begin{array}{l}100 \\
100\end{array}$ & $\begin{array}{l}80.95 \\
75.53\end{array}$ & $-1.70^{c}$ & $-4.22^{\mathrm{a}}$ \\
\hline Log(Blue Collar Workers) & 168 & $\begin{array}{l}100 \\
100\end{array}$ & $\begin{array}{l}85.71 \\
79.64\end{array}$ & $-1.71^{\mathrm{a}}$ & $-4.47^{\mathrm{a}}$ \\
\hline Log(White Collar Workers) & 169 & $\begin{array}{l}100 \\
100\end{array}$ & $\begin{array}{l}81.32 \\
82.90\end{array}$ & $-2.89^{\mathrm{a}}$ & $-2.01^{b}$ \\
\hline \multicolumn{6}{|l|}{ IV. Assets and Investment } \\
\hline Investment/Sales & 168 & $\begin{array}{c}0.0116 \\
-0.0085\end{array}$ & $\begin{array}{l}-0.0361 \\
-0.0580\end{array}$ & $-5.42^{\mathrm{a}}$ & $-10.26^{\mathrm{a}}$ \\
\hline Investment/PPE & 168 & $\begin{array}{l}-0.0036 \\
-0.0126\end{array}$ & $\begin{array}{l}-0.0362 \\
-0.0630\end{array}$ & $-2.85^{\mathrm{a}}$ & $-7.76^{\mathrm{a}}$ \\
\hline V. Output & & & & & \\
\hline Log(Sales) & 170 & $\begin{array}{l}-2.1189 \\
-2.2166\end{array}$ & $\begin{array}{l}-1.6950 \\
-1.7275\end{array}$ & $-1.91^{\mathrm{a}}$ & $2.70^{\mathrm{a}}$ \\
\hline \multicolumn{6}{|l|}{ VI. Net Taxes } \\
\hline Net Taxes/Sales & 168 & $\begin{array}{l}-0.0943 \\
-0.0168\end{array}$ & $\begin{array}{l}0.0671 \\
0.0602\end{array}$ & $4.08^{\mathrm{a}}$ & $10.18^{a}$ \\
\hline $\begin{array}{l}\text { Net Taxes } \\
\end{array}$ & 168 & $\begin{array}{l}-766.69 \\
-8.5112\end{array}$ & $\begin{array}{c}25,675.14 \\
2,153.29\end{array}$ & $2.19^{b}$ & $10.53^{\mathrm{a}}$ \\
\hline
\end{tabular}

$\mathrm{a}=$ Significant at $1 \%$ level; $\mathrm{b}=$-Significant at $5 \%$ level; $\mathrm{c}=$ Significant at $10 \%$ level. 
Table 6 - A

Comparisons of Performance Changes in Competitive versus Non-Competitive Industries

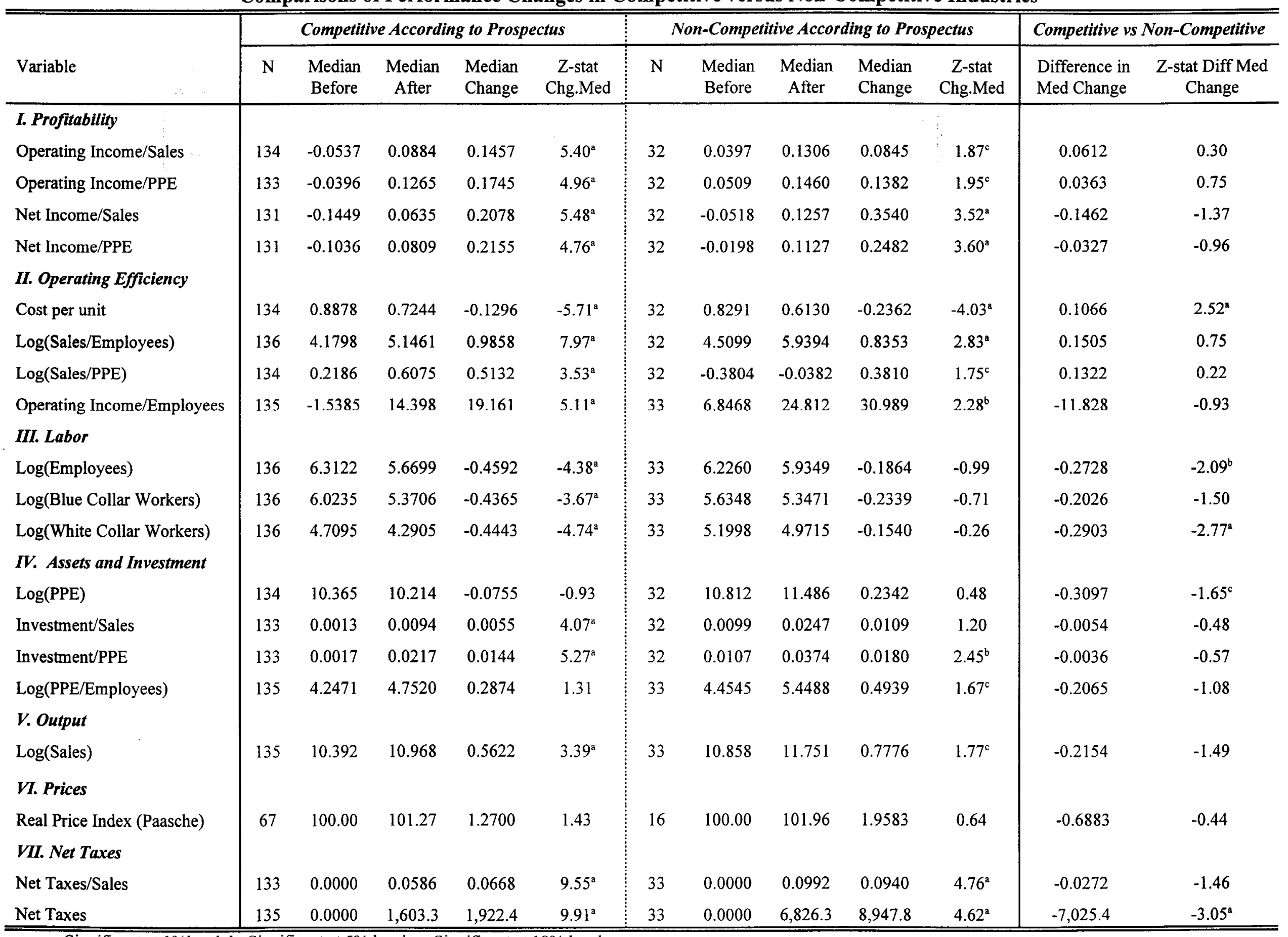


Table 6 - B

Comparisons of Performance Changes in Competitive versus Non-Competitive Industries

\begin{tabular}{|c|c|c|c|c|c|c|c|c|c|c|c|c|}
\hline \multirow[b]{2}{*}{ Variable } & \multicolumn{5}{|c|}{ Number of Firms in Industry $\geq 10$} & \multicolumn{5}{|c|}{ Number of Firms in Industry $<10$} & \multicolumn{2}{|c|}{ Competitive us Non Competitive. } \\
\hline & $\mathrm{N}$ & $\begin{array}{l}\text { Median } \\
\text { Before }\end{array}$ & $\begin{array}{l}\text { Median } \\
\text { After }\end{array}$ & $\begin{array}{l}\text { Median } \\
\text { Change }\end{array}$ & $\begin{array}{c}\text { Z-stat } \\
\text { Chg.Med }\end{array}$ & $\mathrm{N}$ & $\begin{array}{l}\text { Median } \\
\text { Before }\end{array}$ & $\begin{array}{c}\text { Median } \\
\text { After }\end{array}$ & $\begin{array}{l}\text { Median } \\
\text { Change }\end{array}$ & $\begin{array}{c}\text { Z-stat } \\
\text { Chg.Med }\end{array}$ & $\begin{array}{l}\text { Difference } \\
\text { Med Change }\end{array}$ & $\begin{array}{l}\text { Z-stat Diff } \\
\text { Med Change }\end{array}$ \\
\hline \multicolumn{13}{|l|}{ I. Profitability } \\
\hline Operating Income/Sales & 124 & -0.0513 & 0.0778 & 0.1365 & $4.83^{\mathrm{a}}$ & 42 & 0.0299 & 0.1369 & 0.1334 & $3.26^{\mathrm{a}}$ & 0.0031 & 0.94 \\
\hline Operating Income/PPE & 124 & -0.0496 & 0.1129 & 0.1714 & $4.63^{a}$ & 42 & 0.0400 & 0.1474 & 0.1698 & $2.85^{\mathrm{a}}$ & 0.0016 & 0.31 \\
\hline Net Income/Sales & 122 & -0.1068 & 0.0438 & 0.1838 & $4.75^{\mathrm{a}}$ & 41 & -0.1449 & 0.1262 & 0.4260 & $4.61^{\mathrm{a}}$ & -0.2422 & $-2.40^{\mathrm{b}}$ \\
\hline Net Income/PPE & 122 & -0.1119 & 0.0678 & 0.2102 & $4.01^{a}$ & 41 & -0.0435 & 0.2488 & 0.2781 & $4.90^{a}$ & -0.0679 & -1.43 \\
\hline \multicolumn{13}{|l|}{ II. Operating Efficiency } \\
\hline Cost per unit & 124 & 0.8908 & 0.7699 & -0.1255 & $-5.04^{\mathrm{a}}$ & 42 & 0.8163 & 0.6013 & -0.2362 & $-5.59^{\mathrm{a}}$ & 0.1107 & $2.85^{\mathrm{a}}$ \\
\hline Log(Sales/Employees) & 126 & 4.1723 & 5.1725 & 1.0093 & $8.09^{\mathrm{a}}$ & 43 & 4.6066 & 5.4840 & 0.7875 & $3.09^{\mathrm{a}}$ & 0.2218 & 1.01 \\
\hline Log(Sales/PPE) & 124 & 0.2261 & 0.5907 & 0.5882 & $3.07^{\mathrm{a}}$ & 42 & -0.3804 & 0.1188 & 0.3313 & $2.52^{\mathrm{a}}$ & 0.2569 & 0.47 \\
\hline $\begin{array}{l}\text { Operating Income/Employees } \\
\text { II. Labor }\end{array}$ & 125 & -1.5591 & 15.242 & 20.023 & $4.86^{\mathrm{a}}$ & 43 & 3.1796 & 17.088 & 20.932 & $2.80^{\mathrm{a}}$ & -0.9090 & 0.80 \\
\hline Log(Employees) & 126 & 6.3148 & 5.7626 & -0.4346 & $-4.03^{\mathrm{a}}$ & 43 & 6.1570 & 5.5722 & -0.3592 & $-1.90^{c}$ & -0.0754 & -0.77 \\
\hline Log(Blue Collar Workers) & 126 & 6.0361 & 5.3958 & -0.4248 & $-3.37^{\mathrm{a}}$ & 43 & 5.6348 & 5.1985 & -0.2473 & -1.40 & -0.1775 & -0.80 \\
\hline Log(White Collar Workers) & 126 & 4.7500 & 4.3307 & -0.4249 & $-3.81^{\mathrm{a}}$ & 43 & 4.9273 & 4.3983 & -0.3342 & $-1.79^{\mathfrak{c}}$ & -0.0907 & -0.16 \\
\hline \multicolumn{13}{|l|}{ IV. Assets and Investment } \\
\hline $\log (P P E)$ & 124 & 10.365 & 10.428 & 0.0784 & 0.48 & 42 & 10.768 & 11.221 & 0.0231 & 0.27 & 0.0553 & 0.44 \\
\hline Investment/Sales & 123 & 0.0012 & 0.0093 & 0.0060 & $4.22^{\mathrm{a}}$ & 42 & 0.0104 & 0.0247 & 0.0098 & 1.21 & -0.0038 & -0.14 \\
\hline Investment/PPE & 123 & 0.0017 & 0.0214 & 0.0144 & $5.49^{\mathrm{a}}$ & 42 & 0.0128 & 0.0322 & 0.0180 & $2.41^{b}$ & -0.0036 & -0.81 \\
\hline Log(PPE/Employees) & 125 & 4.1948 & 4.7922 & 0.3887 & $1.77^{\mathrm{c}}$ & 43 & 4.4550 & 5.0074 & 0.2186 & 0.85 & 0.1701 & 0.40 \\
\hline \multicolumn{13}{|l|}{ V. Output } \\
\hline Log(Sales) & 124 & 10.423 & 11.098 & 0.6479 & $3.83^{\mathrm{a}}$ & 42 & 10.389 & 11.119 & 0.3752 & 1.20 & 0.2727 & 0.39 \\
\hline \multicolumn{13}{|l|}{ VI. Prices } \\
\hline Index of Real Prices (Paasche) & 66 & 100.00 & 102.10 & 2.1034 & $2.57^{\mathrm{b}}$ & 17 & 100.00 & 96.36 & -3.6400 & -1.56 & 5.7434 & 1.16 \\
\hline \multicolumn{13}{|l|}{ VII. Net Taxes } \\
\hline Net Taxes/Sales & 124 & 0.0000 & 0.0511 & 0.0717 & $9.28^{a}$ & 41 & 0.0000 & 0.1000 & 0.0897 & $5.53^{\mathrm{a}}$ & -0.0180 & -0.93 \\
\hline Net Taxes & 124 & 0.0000 & $1,694.2$ & $1,960.4$ & $9.79^{a}$ & 42 & 0.0000 & $4,433.7$ & $3,822.1$ & $5.00^{\mathrm{a}}$ & $-1,861.7$ & -1.39 \\
\hline
\end{tabular}


Table 6 - C

Comparisons of Performance Changes in Competitive versus Non-Competitive Industries

\begin{tabular}{|c|c|c|c|c|c|c|c|c|c|c|c|c|}
\hline \multirow[b]{2}{*}{ C Variable } & \multicolumn{5}{|c|}{ Initial Mkt Share $\leq 10 \%$} & \multicolumn{5}{|c|}{ Initial Mkt Share > 10\% } & \multicolumn{2}{|c|}{ Competitive vs. Non-Competitive } \\
\hline & $\mathrm{N}$ & $\begin{array}{c}\text { Median } \\
\text { Before }\end{array}$ & $\begin{array}{c}\text { Median } \\
\text { After }\end{array}$ & $\begin{array}{l}\text { Median } \\
\text { Change }\end{array}$ & $\begin{array}{c}\text { Z-stat } \\
\text { Chg.Med }\end{array}$ & $\mathrm{N}$ & $\begin{array}{l}\text { Median } \\
\text { Before }\end{array}$ & $\begin{array}{c}\text { Median } \\
\text { After }\end{array}$ & $\begin{array}{l}\text { Median } \\
\text { Change }\end{array}$ & $\begin{array}{c}\text { Z-stat } \\
\text { Chg.Med }\end{array}$ & $\begin{array}{l}\text { Difference in } \\
\text { Med Change }\end{array}$ & $\begin{array}{l}\text { Z-stat Diff } \\
\text { Med Change }\end{array}$ \\
\hline \multicolumn{13}{|l|}{ I. Profitability } \\
\hline Operating Income/Sales & 104 & -0.0782 & 0.0700 & 0.1799 & $5.03^{\mathrm{a}}$ & 62 & 0.4815 & 0.1333 & 0.0712 & $2.87^{\mathrm{a}}$ & 0.1087 & 1.06 \\
\hline Operating Income/PPE & 103 & -0.0827 & 0.1042 & 0.1832 & $4.66^{a}$ & 62 & 0.0694 & 0.1596 & 0.1222 & $2.77^{\mathrm{c}}$ & 0.0610 & 1.28 \\
\hline Net Income/Sales & 101 & -0.1968 & 0.0438 & 0.2263 & $4.51^{\mathrm{a}}$ & 62 & -0.0401 & 0.0992 & 0.2524 & $4.81^{\mathrm{a}}$ & -0.0261 & -0.95 \\
\hline Net Income/PPE & 101 & -0.1432 & 0.0550 & 0.2015 & $3.84^{\mathrm{a}}$ & 62 & -0.0198 & 0.1955 & 0.2716 & $4.75^{\mathrm{a}}$ & -0.0701 & -0.84 \\
\hline \multicolumn{13}{|l|}{ II. Operating Efficiency } \\
\hline Cost per unit & 104 & 0.9043 & 0.7755 & 0.1415 & $-4.83^{\mathrm{a}}$ & 62 & 0.8163 & 0.6371 & 0.1907 & $-5.38^{a}$ & -0.0492 & -1.53 \\
\hline Log(Sales/Employees) & 107 & 4.1606 & 5.1765 & 1.0775 & $7.92^{\mathrm{a}}$ & 62 & 4.4016 & 5.1963 & 0.7474 & $3.47^{\mathrm{a}}$ & 0.3301 & $2.43^{b}$ \\
\hline Log(Sales/PPE) & 104 & 0.1849 & 0.6867 & 0.6429 & $3.10^{2}$ & 62 & -0.0844 & 0.1742 & 0.2859 & $2.20^{\mathrm{b}}$ & 0.3570 & 0.49 \\
\hline $\begin{array}{l}\text { Operating Income/Employees } \\
\text { III. Labor }\end{array}$ & 106 & -4.3734 & 16.103 & 22.444 & $4.86^{\mathrm{a}}$ & 62 & 6.7253 & 14.383 & 14.911 & $2.61^{\mathrm{a}}$ & 7.5330 & 0.34 \\
\hline Log(Employees) & 107 & 6.3166 & 5.7137 & -0.4339 & $-4.05^{\mathrm{a}}$ & 62 & 6.2542 & 5.7526 & -0.3645 & $-2.04^{b}$ & -0.0694 & -1.05 \\
\hline Log(Blue Collar Workers) & 107 & 6.0298 & 5.3132 & -0.4440 & $-3.74^{\mathrm{a}}$ & 62 & 5.7719 & 5.4026 & -0.2518 & -1.03 & -0.1922 & -1.47 \\
\hline Log(White Collar Workers) & 107 & 4.6913 & 4.3107 & -0.3286 & $-3.70^{\mathrm{a}}$ & 62 & 4.9163 & 4.4659 & -0.4443 & $-2.14^{b}$ & 0.1157 & 0.23 \\
\hline \multicolumn{13}{|l|}{ IV. Assets and Investment } \\
\hline $\log (P P E)$ & 104 & 10.356 & 10.294 & -0.0823 & -0.53 & 62 & 10.627 & 11.055 & 0.0662 & -0.16 & -0.1485 & -0.03 \\
\hline Investment/Sales & 104 & 0.0010 & 0.0078 & 0.0048 & $3.62^{\mathrm{a}}$ & 62 & 0.0049 & 0.0220 & 0.0096 & $2.33^{b}$ & -0.0048 & -0.80 \\
\hline Investment/PPE & 104 & 0.0014 & 0.0197 & 0.0144 & $4.95^{\mathrm{a}}$ & 62 & 0.0107 & 0.0276 & 0.0191 & $3.18^{\mathrm{a}}$ & -0.0047 & -1.34 \\
\hline Log(PPE/Employees) & 106 & 4.2725 & 4.7149 & 0.3381 & 1.20 & 62 & 4.4100 & 5.0074 & 0.3869 & 1.46 & -0.0488 & -0.03 \\
\hline \multicolumn{13}{|l|}{ V. Output } \\
\hline Log(Sales) & 105 & 10.392 & 11.098 & 0.6479 & $3.97^{\mathrm{a}}$ & 61 & 10.896 & 11.185 & 0.4419 & 1.36 & 0.2060 & 0.99 \\
\hline \multicolumn{13}{|l|}{ VI. Prices } \\
\hline Index of Real Prices (Paasche) & 53 & 100.00 & 105.48 & 5.4780 & $2.69^{\mathrm{a}}$ & 30 & 100.00 & 97.18 & -2.8248 & -0.95 & 8.3028 & $1.87^{\mathrm{c}}$ \\
\hline \multicolumn{13}{|l|}{ VII. Net Taxes } \\
\hline Net Taxes/Sales & 104 & 0.0000 & 0.0413 & 0.0675 & $9.00^{\mathrm{a}}$ & 61 & 0.0077 & 0.0985 & 0.0815 & $6.65^{\mathrm{a}}$ & -0.0140 & -0.72 \\
\hline Net Taxes & 106 & 0.0000 & $1,512.9$ & $2,009.7$ & $9.69^{a}$ & 61 & 167.99 & $3,457.5$ & $3,023.3$ & $5.76^{\mathrm{a}}$ & $-1,013.6$ & -1.30 \\
\hline
\end{tabular}

$\mathrm{a}=$ Significant at $1 \%$ level; $\mathrm{b}=$ Significant at $5 \%$ level; $\mathrm{c}=$ Significant at $10 \%$ level. 


\section{Table 7: The Role of Transfers from Workers}

This table presents empirical results for the sample of 101 privatized firms that have wage data available. The table presents, for each empirical proxy, the number of usable observations, the mean and median values of the proxy before privatization and the mean and median value for the proxy in 1993. The table is divided in two panels. Panel A contains statistics for all 101 firms with available wage data. Panel B describes the wage behavior for the subsample of firms that increased the number of employees after privatization. We report t-statistics and z-statistics (Wilcoxon rank sum) as our test for significance for the change in mean and median values, respectively. Definitions for each variable can be found on Table 3.

\begin{tabular}{|c|c|c|c|c|}
\hline Variable & $\mathrm{N}$ & $\begin{array}{l}\text { Mean Before } \\
\text { (Median) }\end{array}$ & $\begin{array}{l}\text { Mean in } 1993 \\
\text { (Median) }\end{array}$ & $\begin{array}{c}\text { t-stat for change } \\
\text { (Z-test) }\end{array}$ \\
\hline \multicolumn{5}{|c|}{ Panel A: All firms with available wage data } \\
\hline \multirow[t]{2}{*}{ Wages per worker } & 101 & $N \$ 15,074$ & $\mathrm{~N} \$ 27,079$ & $5.42^{\mathrm{a}}$ \\
\hline & & $N \$ 9,995$ & $\mathrm{~N} \$ 22,481$ & $6.05^{\mathrm{a}}$ \\
\hline Index $\Lambda$ djusted Wages & 101 & 100 & 214.17 & $7.62^{\mathrm{a}}$ \\
\hline Relative to Global Wages & & 100 & 199.06 & $6.24^{\mathrm{a}}$ \\
\hline \multirow[t]{2}{*}{ Blue Collar Wage } & 101 & $N \$ 9,525$ & $\mathrm{~N} \$ 22,425$ & $5.72^{\mathrm{a}}$ \\
\hline & & $N \$ 6,791$ & $N \$ 16,851$ & $7.45^{\mathrm{a}}$ \\
\hline Index Blue Collar Wages & 101 & 100 & 275.43 & $8.45^{\mathrm{a}}$ \\
\hline Relative to Global Wages & & 100 & 224.13 & $7.77^{\mathrm{a}}$ \\
\hline \multirow[t]{2}{*}{ White Collar Wage } & 101 & $N \$ 27,992$ & $N \$ 44,301$ & $4.13^{a}$ \\
\hline & & $N \$ 18,892$ & $N \$ 37,964$ & $5.17^{\mathrm{a}}$ \\
\hline Index White Collar Wages & 101 & 100 & 177.99 & $5.80^{\mathrm{a}}$ \\
\hline Relative to Global Wages & & 100 & 146.68 & $6.24^{\mathrm{a}}$ \\
\hline \multirow[t]{2}{*}{ Total Wages/Sales } & 101 & 0.2338 & 0.1441 & $-3.14^{\mathrm{a}}$ \\
\hline & & 0.1506 & 0.1143 & $-2.93^{\mathrm{a}}$ \\
\hline \multirow[t]{2}{*}{ Log(Employees) } & 101 & 6.4405 & 5.8944 & $-2.95^{\mathrm{a}}$ \\
\hline & & 6.4708 & 5.9269 & $-2.99^{\mathrm{a}}$ \\
\hline \multirow[t]{2}{*}{ Operating Income/Sales } & 101 & -0.1530 & 0.0682 & $4.23^{\mathrm{a}}$ \\
\hline & & -0.0251 & 0.0708 & $4.16^{a}$ \\
\hline
\end{tabular}

Panel B: Firms with available wage data that increased the number of workers after privatization

\begin{tabular}{lcccr} 
Wages per worker & 20 & $\mathrm{~N} \$ 12,727$ & $\mathrm{~N} \$ 26,203$ & $2.32^{\mathrm{b}}$ \\
& & $\mathrm{N} \$ 9,473$ & $\mathrm{~N} \$ 19,936$ & $2.62^{\mathrm{a}}$ \\
Blue Collar Wage & 20 & $\mathrm{~N} \$ 8,679$ & $\mathrm{~N} \$ 19,608$ & $2.65^{\mathrm{a}}$ \\
& & $\mathrm{N} \$ 6,834$ & $\mathrm{~N} \$ 14,361$ & $3.28^{\mathrm{a}}$ \\
White Collar Wage & \multirow{2}{*}{20} & $\mathrm{~N} \$ 22,003$ & $\mathrm{~N} \$ 52,038$ & $2.06^{\mathrm{b}}$ \\
& & $\mathrm{N} \$ 15,010$ & $\mathrm{~N} \$ 37,602$ & $3.25^{\mathrm{a}}$ \\
Log(Employees) & \multirow{2}{*}{20} & 6.2785 & 6.6788 & 0.98 \\
& & 6.3966 & 6.7440 & $1.76^{\mathrm{c}}$ \\
\hline \hline
\end{tabular}

$\mathrm{a}=$ Significant at $1 \%$ level; $\mathrm{b}=$ Significant at $5 \%$ level; $\mathrm{c}=$ Significant at $10 \%$ level. 


\section{Table 8: Regression Results}

The table reports results from OLS regressions for the cross-section of 170 privatized firms. All regressions include--but we do not report-eight dummies for privatization cohorts. White (1980) error-corrected standard errors are reported in parenthesis. The dependent variables are: (1) Adj $\triangle \mathrm{OI} / \mathrm{S}$--the change in the industry-adjusted operating-income-to-sales ratio; (2) Adj $\triangle \mathrm{NI} / \mathrm{S}$--the change in the industry-adjusted net-income-to-sales ratio; (3) $\mathrm{Adj} \Delta \mathrm{C} / \mathrm{S}$--the change in the industry-adjusted costs-per-unit; (4) $\mathrm{Adj} \Delta \mathrm{S} / \mathrm{L}$--the change in the industryadjusted sales-to-labor ratio; (5) $\mathrm{Adj} \Delta \mathrm{L}$--the growth in employment relative to the industry; (6) Adj I/PPE --the industry-adjusted investment-to-fixed-assets ratio; and (7) $\mathrm{Adj} \Delta \mathrm{S}$--the industry-adjusted growth in sales. The independent variables are: (1) Monopoly or Oligopoly --a dummy variable that takes value of one if the prospectus describes the industry in which the firm operates as monopolistic or oligopolistic and zero otherwise; (2) Price/Quantity controlled --a dummy that takes value of one if price of the firm's output or its quantity is controlled by the government and zero otherwise; (3) FDI restricted --a dummy variable that takes value of one if foreigners are not allowed to own majority stakes in the sector in which the firm operates and zero otherwise; (4) Revenue privatization- a dummy that takes value of one if the state owned a non-control package before the transaction took place and zero otherwise; (5) Outside buyer --a dummy variable that takes value of one if the SOE is sold to a buyer with no experience in the same three-digit level SIC classification and zero otherwise; (6) Nontraded good -- a dummy variable that takes value of one if it is not possible to trade internationally the firm's output and zero otherwise; (7) Number of strikes --the total number of strikes in the five years that precede privatization; and (8) the preprivatization value of the relevant dependent variable.

\begin{tabular}{|c|c|c|c|c|c|c|c|}
\hline Independent / Dependent Variable & $\operatorname{Adj} \Delta \mathrm{OI} / \mathrm{S}$ & $\operatorname{Adj} \Delta \mathrm{NI} / \mathrm{S}$ & $\operatorname{Adj} \Delta \mathrm{C} / \mathrm{S}$ & $\operatorname{Adj} \Delta S / L$ & Adj $\Delta \mathrm{L}$ & Adj I/PPE & $\operatorname{Adj} \Delta S$ \\
\hline Monopoly or Oligopoly & $\begin{array}{c}0.0240 \\
(0.0623)\end{array}$ & $\begin{array}{c}0.0377 \\
(0.0912)\end{array}$ & $\begin{array}{c}0.0321 \\
(0.0476)\end{array}$ & $\begin{array}{c}-0.2023 \\
(0.2474)\end{array}$ & $\begin{array}{c}0.0987^{b} \\
(0.0491)\end{array}$ & $\begin{array}{c}-0.0184 \\
(0.0295)\end{array}$ & $\begin{array}{c}0.7583^{\mathrm{a}} \\
(0.2455)\end{array}$ \\
\hline Price/Quantity controlled & $\begin{array}{r}-0.1154^{\mathrm{b}} \\
(0.0499)\end{array}$ & $\begin{array}{l}-0.2126^{a} \\
(0.0673)\end{array}$ & $\begin{array}{c}0.1679^{a} \\
(0.0419)\end{array}$ & $\begin{array}{l}-0.3347^{b} \\
(0.1707)\end{array}$ & $\begin{array}{c}0.0661^{\mathrm{c}} \\
(0.0395)\end{array}$ & $\begin{array}{c}-0.0385^{\mathrm{b}} \\
(0.0186)\end{array}$ & $\begin{array}{c}0.4368^{a} \\
(0.1665)\end{array}$ \\
\hline FDI restricted & $\begin{array}{c}0.0611 \\
(0.0534)\end{array}$ & $\begin{array}{c}0.0178 \\
(0.0750)\end{array}$ & $\begin{array}{c}-0.0591 \\
(0.0399)\end{array}$ & $\begin{array}{c}0.1799 \\
(0.2056)\end{array}$ & $\begin{array}{l}-0.0364 \\
(0.0378)\end{array}$ & $\begin{array}{c}0.0818^{b} \\
(0.0380)\end{array}$ & $\begin{array}{c}-0.1409 \\
(0.2020)\end{array}$ \\
\hline Revenue privatization & $\begin{array}{c}0.0415 \\
(0.0690)\end{array}$ & $\begin{array}{c}0.0381 \\
(0.1036)\end{array}$ & $\begin{array}{c}0.0149 \\
(0.0589)\end{array}$ & $\begin{array}{c}-0.1038 \\
(0.3481)\end{array}$ & $\begin{array}{c}-0.0643 \\
(0.0766)\end{array}$ & $\begin{array}{c}0.0348 \\
(0.0500)\end{array}$ & $\begin{array}{c}-0.0554 \\
(0.3288)\end{array}$ \\
\hline Outside buyer & $\begin{array}{c}0.0085 \\
(0.1773)\end{array}$ & $\begin{array}{c}0.0961 \\
(0.2622)\end{array}$ & $\begin{array}{c}0.0089 \\
(0.1281)\end{array}$ & $\begin{array}{l}-0.6394^{c} \\
(0.3710)\end{array}$ & $\begin{array}{c}-0.0333 \\
(0.0708)\end{array}$ & $\begin{array}{l}-0.0345 \\
(0.0436)\end{array}$ & $\begin{array}{l}-0.7967^{\mathrm{b}} \\
(0.3980)\end{array}$ \\
\hline Non-traded good & $\begin{array}{c}0.0750 \\
(0.0929)\end{array}$ & $\begin{array}{c}0.0436 \\
(0.1180)\end{array}$ & $\begin{array}{l}-0.1144^{\mathrm{c}} \\
(0.0616)\end{array}$ & $\begin{array}{l}-0.1071 \\
(0.2804)\end{array}$ & $\begin{array}{c}0.0549 \\
(0.0419)\end{array}$ & $\begin{array}{c}0.0354 \\
(0.0386)\end{array}$ & $\begin{array}{c}0.1997 \\
(0.2543)\end{array}$ \\
\hline Number of Strikes & $\begin{array}{c}-0.1961 \\
(0.0149)\end{array}$ & $\begin{array}{l}-0.0378^{b} \\
(0.0188)\end{array}$ & $\begin{array}{c}0.0106 \\
(0.0096)\end{array}$ & $\begin{array}{c}-0.0405 \\
(0.0417)\end{array}$ & $\begin{array}{c}0.0021 \\
(0.0114)\end{array}$ & $\begin{array}{l}-0.0030 \\
(0.0068)\end{array}$ & $\begin{array}{c}-0.0215 \\
(0.0526)\end{array}$ \\
\hline $\operatorname{Adj~OI/S~to~}$ & $\begin{array}{l}-1.0658^{a} \\
(0.0613)\end{array}$ & -- & --- &.- & -- & -- & ... \\
\hline $\operatorname{Adj} N \mathrm{~N} / \mathrm{S}_{\mathrm{t} 0}$ & -- & $\begin{array}{l}-0.9978^{\mathrm{a}} \\
(0.0620)\end{array}$ & --- & --- & $\cdots$ & --- & --- \\
\hline $\operatorname{Adj} R C / S_{\text {to }}$ & -- &.- & $\begin{array}{l}-0.9607^{\mathrm{a}} \\
(0.0764)\end{array}$ & --- & --- & -- & -- \\
\hline $\operatorname{Adj} S / L_{w}$ & --- & --- & -- & $\begin{array}{l}-0.3920^{\mathrm{a}} \\
(0.0806)\end{array}$ & --- & -- & -- \\
\hline $\operatorname{Adj} \Delta L_{\mathfrak{1 0}}$ & -- & -- & --- & $-\cdots$ & $\begin{array}{c}-1.0872^{b} \\
(0.4385)\end{array}$ & -- & $\cdots$ \\
\hline $\mathrm{I} / \mathrm{PPE}_{t 0}$ & --- & --- & -- & --- & --- & $\begin{array}{c}-0.3652 \\
(0.3244)\end{array}$ & -- \\
\hline Adj Sales $_{\text {to }}$ & --- & --- & -- & --- & --- & --- & $\begin{array}{l}-0.1702^{\star} \\
(0.0547)\end{array}$ \\
\hline Constant & $\begin{array}{c}0.0595^{a} \\
(0.0208) \\
\end{array}$ & $\begin{array}{r}0.0665^{\mathrm{s}} \\
(0.0206) \\
\end{array}$ & $\begin{array}{c}0.0055 \\
(0.0307) \\
\end{array}$ & $\begin{array}{r}1.7247^{\mathrm{a}} \\
(0.0928) \\
\end{array}$ & $\begin{array}{r}-0.4564^{\mathrm{a}} \\
(0.0313) \\
\end{array}$ & $\begin{array}{l}-0.0269^{\mathrm{a}} \\
(0.0082) \\
\end{array}$ & $\begin{array}{r}-0.0835 \\
(0.0541) \\
\end{array}$ \\
\hline Number of Observations & 163 & 160 & 163 & 138 & 164 & 162 & 165 \\
\hline$\therefore \ldots \therefore+\ldots$ & 0.5926 & 0.6179 & 0.4673 & 0.1700 & 0.2039 & 0.1143 & 0.1665 \\
\hline
\end{tabular}

$\mathrm{a}=$ Significant at $1 \%$ level; $\mathrm{b}=$ Significant at $5 \%$ level; $\mathrm{c}=$ Significant at $10 \%$ level. 
Appendix A

Summary Statistics of the Variables used in Table 4

\begin{tabular}{|c|c|c|c|c|c|c|}
\hline Variable & Obs. & Mean & Median & Std. Dev. & Minimum & Maximum \\
\hline \multicolumn{7}{|l|}{ I. Profitability } \\
\hline Operating Income/Sales pre-privatization & 170 & -0.1545 & -0.0273 & 0.4817 & -3.1204 & 0.6261 \\
\hline Operating Income/Sales post-privatization & 170 & 0.0891 & 0.0940 & 0.3075 & -0.08746 & 0.8720 \\
\hline Net Income/Sales pre-privatization & 170 & -0.3632 & -0.1297 & 0.9658 & -9.2105 & 0.7274 \\
\hline Net Income/Sales post-privatization & 170 & 0.0381 & 0.0770 & 0.4255 & -1.5300 & 1.1038 \\
\hline Operating Income/PPE pre-privatization & 170 & -0.1052 & -0.0141 & 0.4361 & -1.4137 & 0.5463 \\
\hline Operating Income/PPE post-privatization & 170 & 0.2392 & 0.1345 & 0.9238 & -1.9203 & 2.3906 \\
\hline Net Income/PPE pre-privatization & 170 & -0.2176 & -0.0728 & 0.4245 & -1.4815 & 0.3033 \\
\hline Net Income/PPE post-privatization & 170 & 0.0538 & 0.0815 & 1.2926 & -2.9926 & 2.8114 \\
\hline \multicolumn{7}{|l|}{ II. Operating Efficiency } \\
\hline Cost per unit pre-privatization & 170 & 0.9166 & 0.8804 & 0.3274 & 0.3325 & 2.9286 \\
\hline Cost per unit post-privatization & 170 & 0.6989 & 0.7108 & 0.2576 & 0.1018 & 1.6214 \\
\hline Log (Sales/PPE) pre-privatization & 170 & 0.0569 & 0.1679 & 1.2473 & -3.8407 & 5.6194 \\
\hline Log (Sales/PPE) post-privatization & 169 & 0.7033 & 0.4064 & 1.5252 & -2.4799 & 6.8023 \\
\hline Log (Sales/Employees) pre-privatization & 169 & 4.3689 & 4.2059 & 0.9980 & 1.5890 & 8.8146 \\
\hline Log (Sales/Employees) post-privatization & 169 & 5.4050 & 5.1910 & 1.2856 & 2.2349 & 12.5929 \\
\hline Operating Income/Employees pre-privatization & 169 & 1.6373 & -0.6123 & 25.5263 & -41.4510 & 70.0274 \\
\hline Operating Income/Employee post-privatization & 169 & 52.6703 & 16.0713 & 100.9298 & -57.0554 & 343.6274 \\
\hline \multicolumn{7}{|l|}{ III. Labor } \\
\hline Log (Employees) pre-privatization & 169 & 6.1634 & 6.2975 & 1.6501 & 1.3862 & 10.7883 \\
\hline Log (Employees) post-privatization & 169 & 5.5361 & 5.7235 & 1.5097 & 0 & 10.8176 \\
\hline Log (Blue Collar Workers) pre-privatization & 168 & 5.8262 & 5.9648 & 1.2016 & 2.8903 & 10.6235 \\
\hline Log (Blue Collar Workers) post-privatization & 168 & 5.3260 & 5.3612 & 1.3941 & 0 & 10.6529 \\
\hline Log (White Collar Workers) pre-privatization & 169 & 4.8272 & 4.7874 & 1.0745 & 1.3862 & 8.9038 \\
\hline Log (White Collar Workers) post-privatization & 169 & 4.3210 & 4.3307 & 1.2491 & 0 & 8.9326 \\
\hline \multicolumn{7}{|l|}{ IV.Assets and Investment } \\
\hline Log (PPE) pre-privatization & 170 & 10.5193 & 10.4581 & 1.8314 & 5.8478 & 16.8877 \\
\hline Log (PPE) post-privatization & 170 & 10.2394 & 10.5496 & 2.4931 & 0.6931 & 17.4042 \\
\hline Investment/Sales pre-privatization & 170 & 0.0299 & 0.0021 & 0.0648 & 0 & \\
\hline Investment/Sales post-privatization & 170 & 0.0448 & 0.0126 & 0.0878 & 0 & 0.5191 \\
\hline Investment/Employees pre-privatization & 169 & 3.1664 & 0.1335 & 7.2044 & -0.0049 & 28.0812 \\
\hline Investment/Employees post-privatization & 169 & 10.2762 & 2.7184 & 18.3302 & 0 & 74.4744 \\
\hline
\end{tabular}




\begin{tabular}{|c|c|c|c|c|c|c|}
\hline Variable & Obs. & Mean & Median & Std. Dev. & Minimum & Maximum \\
\hline Investment/PPE pre-privatization & 170 & 0.0244 & 0.0039 & 0.0439 & -0.0224 & 0.1658 \\
\hline Investment/PPE post-privatization & 170 & 0.0714 & 0.0254 & 0.1292 & 0 & 1 \\
\hline Log (PPE/Employees) pre-privatization & 169 & 4.4689 & 4.3076 & 1.2152 & 1.3009 & 7.6334 \\
\hline Log (PPE/Employees) post-privatization & 169 & 4.6614 & 4.8263 & 1.8591 & -0.0825 & 12.6563 \\
\hline \multicolumn{7}{|l|}{ V.Output } \\
\hline Log (Sales) pre-privatization & 170 & 10.4746 & 10.4168 & 1.4905 & 6.2158 & 15.8956 \\
\hline Log (Sales) post-privatization & 170 & 11.0174 & 11.0984 & 1.5725 & 7.3240 & 17.0183 \\
\hline \multicolumn{7}{|l|}{ VI. Prices } \\
\hline Index of Real Prices pre-privatization (Paasche) & 83 & 100.000 & 100.000 & 0 & 100.000 & 100.000 \\
\hline Index of Real Prices post-privatization (Paasche) & 83 & 102.866 & 101.270 & 34.577 & 32.157 & 249.168 \\
\hline Index of Real Prices pre-privatization (Laspayres) & 83 & 100.000 & 100.000 & 0 & 100.000 & 100.000 \\
\hline Index of Real Prices post-privatization (Laspayres) & 83 & 103.292 & 101.725 & 34.617 & 32.157 & 249.168 \\
\hline \multicolumn{7}{|l|}{ VII. Net Taxes } \\
\hline Net Taxes/Sales pre-privatization & 170 & -0.0462 & 0 & 0.2174 & -1.5531 & 0.5737 \\
\hline Net Taxes/Sales post-privatization & 170 & 0.0834 & 0.0741 & 0.1029 & 0 & 0.8938 \\
\hline Net Taxes pre-privatization & 170 & -760.2429 & 0 & 53109.36 & -195713.4 & 580667.7 \\
\hline Net Taxes post-privatization & 170 & 25531.24 & 2088.35 & 146266.7 & 0 & 1824017 \\
\hline
\end{tabular}


Appendix B

Summary Statistics of the Variables used in Table 5

\begin{tabular}{|c|c|c|c|c|c|c|}
\hline Variable & Obs. & Mean & Median & Std. Dev. & Minimum & Maximum \\
\hline \multicolumn{7}{|l|}{ 1. Profitability } \\
\hline Operating Income/Sales pre-privatization & 168 & -0.2975 & -0.1353 & 0.9253 & -11.1102 & 0.4900 \\
\hline Operating Income/Sales post- privatization & 166 & 0.0288 & 0.0178 & 0.2783 & -0.5750 & 0.7991 \\
\hline Operating Income/PPE pre-privatization & 168 & -0.2336 & -0.1470 & 0.4081 & -1.4147 & 0.3973 \\
\hline Operating Income/PPE post-privatization & 168 & 0.0913 & 0.0021 & 0.9349 & -2.1387 & 2.2613 \\
\hline Net Income/Sales pre-privatization & 168 & -0.4035 & -0.1720 & 1.0477 & -11.0501 & 0.6141 \\
\hline Net Income/Sales post-Privatization & 168 & 0.0108 & 0.0401 & 0.4271 & -1.4945 & 1.0535 \\
\hline Net Income/PPE pre-privatization & 168 & -0.2685 & -0.1494 & 0.3779 & -1.3469 & 0.2315 \\
\hline Net Income/PPE post-privatization & 168 & -0.0161 & 0.0241 & 1.3041 & -3.1072 & 2.7542 \\
\hline \multicolumn{7}{|l|}{ II. Operating Efficiency } \\
\hline Cost per unit pre-privatization & 168 & 0.1826 & 0.1422 & 0.3199 & -0.3111 & 2.1910 \\
\hline Cost per unit post-privatization & 168 & -0.0020 & -0.0105 & 0.2720 & -0.6428 & 0.9726 \\
\hline Log (Sales/Employees) pre-privatization & 166 & -1.1836 & -1.3133 & 1.1367 & -4.9877 & 3.6062 \\
\hline Log (Sales/Employees) post-privatization & 166 & -0.2678 & -0.4298 & 1.3223 & -3.2575 & 6.9750 \\
\hline Log (Sales/PPE) pre-privatization & 168 & -0.2850 & -0.1640 & 1.2034 & -5.3905 & 5.3076 \\
\hline Log (Sales/PPE) post-privatization & 168 & 0.1834 & 0.0374 & 1.5264 & -2.6474 & 5.9159 \\
\hline \multicolumn{7}{|l|}{ III. Labor } \\
\hline Log (Employees) pre-privatization & 169 & -0.1180 & -0.08771 & 0.2335 & -1.0262 & 1.1922 \\
\hline Log (Employees) post-privatization & 169 & -0.1905 & -0.2447 & 0.4942 & -0.9196 & 1.1363 \\
\hline Log (Blue Collar Workers) pre-privatization & 168 & -0.0569 & -0.0299 & 0.2114 & -0.9838 & 0.9337 \\
\hline Log (Blue Collar Workers) post-privatization & 168 & -0.1429 & -0.2036 & 0.5995 & -0.9537 & 1.6549 \\
\hline Log (White Collar Workers) pre-privatization & 169 & -0.0617 & -0.0299 & 0.1892 & -0.9701 & 0.4319 \\
\hline $\log$ (White Collar Workers) post-privatization & 169 & 0.1868 & -0.1710 & 1.0741 & -0.8408 & 3.6350 \\
\hline \multicolumn{7}{|l|}{ IV.Assets and Investment } \\
\hline Investment/Sales pre-privatization & 168 & 0.0115 & -0.0088 & 0.0687 & -0.0711 & 0.2439 \\
\hline Investment/Sales post-privatization & 168 & -0.0357 & -0.0579 & 0.0897 & -0.1662 & 0.4372 \\
\hline Investment/PPE pre-privatization & 168 & -0.0037 & -0.0126 & 0.0487 & -0.0921 & 0.1401 \\
\hline Investment/PPE post-privatization & 168 & -0.0365 & -0.0629 & 0.1397 & -0.1498 & 0.9370 \\
\hline \multicolumn{7}{|l|}{ V.Output } \\
\hline Log (Sales) pre-privatization & 170 & -2.1151 & -2.2165 & 1.6056 & -6.7841 & 3.2611 \\
\hline Log (Sales) post-privatization & 170 & -1.6865 & -1.7275 & 1.6836 & -5.6396 & 4.3027 \\
\hline
\end{tabular}




\begin{tabular}{l|c|c|c|c|c|c}
\hline \multicolumn{1}{c|}{ Variable } & Obs. & Mean & Median & Std. Dev. & Minimum & Maximum \\
\hline VI. Net Taxes & & & & & \\
Net Taxes/Sales pre-privatization & 168 & -0.0944 & -0.0167 & 0.4958 & -6.0160 \\
Net Taxes/Sales post-privatization & 168 & 0.0664 & 0.0588 & 0.1048 & -0.0242 & 0.5534 \\
Net Taxes pre-privatization & 168 & -766.6986 & -8.5112 & 53431.63 & -195721.5 \\
Net Taxes post-privatization & 168 & 25522.28 & 2079.71 & 146266.7 & -10.3587 & 1824008 \\
\end{tabular}

$a=$ Significant at $1 \%$ level; $b=$ Significant at $5 \%$ level; $c=$ Significant at $10 \%$ level. 
Appendix C

Summary Statistics for the Variables in Table 7

\begin{tabular}{|c|c|c|c|c|c|c|}
\hline Variable & Obs. & Mean & Median & Std. Dev. & Minimum & Maximum \\
\hline Wages per workers (pre-privatization) & 101 & $\mathrm{~N} \$ 15,074$ & $N \$ 9,995$ & $N \$ 12,378$ & $N \$ 8,446$ & $N \$ 63,637$ \\
\hline Wages per worker (post-privatization) & 101 & $\mathrm{~N} \$ 27,079$ & $\mathrm{~N} \$ 22,481$ & $N \$ 18,521$ & $\mathrm{~N} \$ 2,200$ & $N \$ 104,705$ \\
\hline $\begin{array}{l}\text { Index Adjusted Wages Relative to Global } \\
\text { Wages (pre-privatization) }\end{array}$ & 101 & 100.00 & 100.00 & 0.00 & 100.00 & 100.00 \\
\hline $\begin{array}{l}\text { Index Adjusted Wages Relative to Global } \\
\text { Wages (post-privatization) }\end{array}$ & 101 & 214.17 & 199.07 & 249.07 & 21.51 & 578.59 \\
\hline Blue Collar Wage (pre-privatization) & 101 & $N \$ 9,525$ & $N \$ 6,791$ & $\mathrm{~N} \$ 8,782$ & $N \$ 423$ & $\mathrm{~N} \$ 56,526$ \\
\hline Blue Collar Wage (post-privatization) & 101 & $\mathrm{~N} \$ 22,425$ & $N \$ 16,851$ & $\mathrm{~N} \$ 20,810$ & $\mathrm{~N} \$ 2,200$ & $N \$ 123,769$ \\
\hline $\begin{array}{l}\text { Index Blue Collar Wages Relative to Global } \\
\text { Waged (pre-privatization) }\end{array}$ & 101 & 100.00 & 100.00 & 0.00 & 100.00 & 100.00 \\
\hline $\begin{array}{l}\text { Index Blue Collar Wages Relative to Global } \\
\text { Waged (post-privatization) }\end{array}$ & 101 & 275.43 & 224.12 & 301.29 & 37.19 & 712.32 \\
\hline White Collar Wage (pre-privatization) & 101 & $\mathrm{~N} \$ 27,992$ & $\mathrm{~N} \$ 18,892$ & $N \$ 22,852$ & $N \$ 2,397$ & $N \$ 106,085$ \\
\hline White Collar Wage (post-privatization) & 101 & $N \$ 44,301$ & $\mathrm{~N} \$ 37,964$ & $N \$ 32,408$ & $N \$ 4,628$ & $N \$ 231,548$ \\
\hline $\begin{array}{l}\text { Index White Collar Wages relative to Global } \\
\text { Wages (pre-privatization) }\end{array}$ & 101 & 100.00 & 100.00 & 0.00 & 100.00 & 100.00 \\
\hline $\begin{array}{l}\text { Index White Collar Wages relative to Global } \\
\text { Wages (post-privatization) }\end{array}$ & 101 & 177.99 & 146.68 & 233.13 & 15.20 & 502.90 \\
\hline Total Wages/Sales (pre-privatization) & 101 & 0.2339 & 0.1506 & 0.2409 & 0.0108 & 1.5404 \\
\hline Total Wages/Sales (post-privatization) & 101 & 0.1441 & 0.1144 & 0.1524 & 0.0026 & 0.9690 \\
\hline Log (Employees) (pre-privatization) & 101 & 6.4405 & 6.4708 & 1.1370 & 3.9512 & 10.7883 \\
\hline Log (Employees) (post-privatization) & 101 & 5.8944 & 5.9269 & 1.4710 & 0.6931 & 10.8176 \\
\hline Operating Income/Sales (pre-privatization) & 101 & -0.1530 & -0.0251 & 0.4353 & -2.1968 & 0.4332 \\
\hline Operating Income/Sales (post-privatization) & 101 & 0.0682 & 0.0708 & 0.2882 & -0.8746 & 0.8720 \\
\hline
\end{tabular}


Appendix D

Summary Statistics for the Control Variables used in Table 8

\begin{tabular}{|c|c|c|c|c|c|c|}
\hline Variable & Obs. & Mean & Median & Std. Dev. & Minimum & Maximum \\
\hline Price/Quality controlled & 170 & 0.3294 & 0 & 0.4713 & 0 & 1 \\
\hline FDI restricted & 170 & 0.2294 & 0 & 0.4216 & 0 & 1 \\
\hline Barriers to Trade & 170 & 0.3470 & 0 & 0.4774 & 0 & 1 \\
\hline Monopoly or Oligopoly & 170 & 0.1529 & 0 & 0.3609 & 0 & 1 \\
\hline Revenue privatization & 170 & 0.0941 & 0 & 0.2928 & 0 & 1 \\
\hline Outside Buyer & 170 & 0.0294 & 0 & 0.1694 & 0 & 1 \\
\hline Non-traded good & 170 & 0.0823 & 0 & 0.2757 & 0 & 1 \\
\hline Number of Strikes & 170 & 1.1941 & 1 & 1.4028 & 0 & 11 \\
\hline
\end{tabular}

